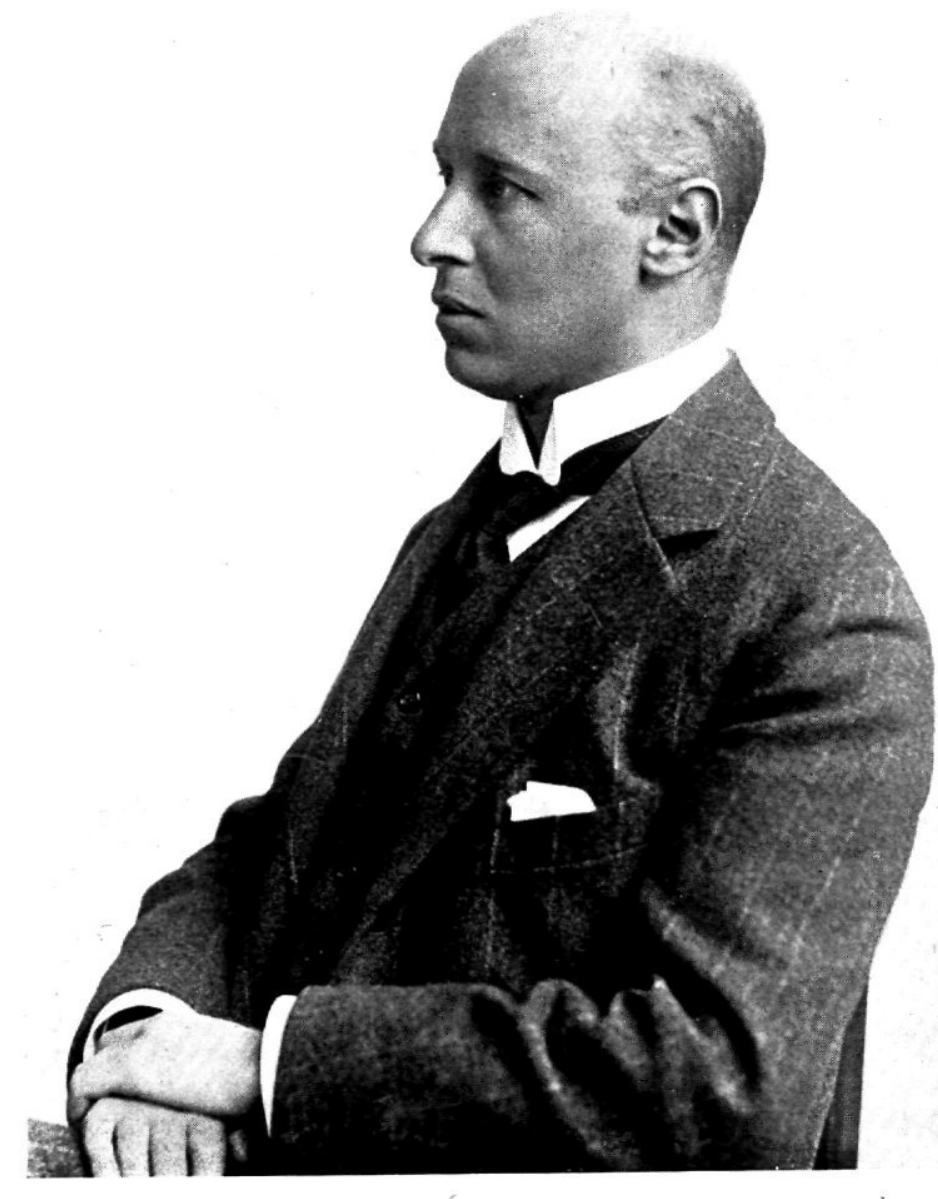

Cranbrelentam 


\title{
Prof. Mr. CORNELIS VAN VOLLENHOVEN ALS ONTDEKKER VAN HET ADATRECHT
}

\author{
DOOR
}

\author{
Mr. F. D. E. VAN OSSENBRUGGEN.
}

Het zou een vermetel bestaan zijn, zich thans reeds te wagen aan eene poging om de geweldige beteekenis van Van Vollenhoven voor de wetenschap, in het bijzonder de rechtswetenschap in al hare onderdeelen, te schetsen, om - zij het slechts in hoofdlijnen - aan te geven, hoe ontzaglijk veel ons land, zijn overzeesch gebied, heel de wetenschappelijke wereld verschuldigd is aan zijn fijn intellect, zijn diep gevoelend hart, zijn hoog zedelijk besef ; eerst veel later zal het mogelijk zijn, zijn waardevol leven en zijn machtigen arbeid volkomen te begrijpen, zich behoorlijk rekenschap te geven van hoe onoverschatbaar belang zijn bestaan is geweest voor tijdgenoot en nazaat. Wie het dàn zou willen ondernemen, om Van Vollenhoven in zijn volle grootheid uit te beelden, zal hem in alles, waarin hij uitblonk, eenigszins moeten evenaren; een zoo zeldzame figuur in al zijn veelzijdigheid te beschrijven, is waarlijk niet een ieders werk. Wat thans geboden wordt, is dan ook niet meer dan een schuchtere poging om in korte trekken op het meest belangrijke te wijzen van hetgeen Van Vollenhoven heeft gedaan voor slechts één enkel deel van het wijdvertakte gebied der rechtswetenschap, hetwelk zijn geest tot in alle onderdeelen onvatte: voor het indonesisch adatrecht.

Het méést belangrijke is eigenlijk reeds met één enkel, alles in zich begrijpend woord gezegd: Van Vollenhoven heeft het adatrecht tot wetenschap verheven. Want moge hetgeen vóór hem op dit gebied geleverd was ook veel waardevols bevatten - ik noem slechts Snouck Hurgronje, Wilken, Liefrinck -, een ,adatrechtswetenschap” bestond vóór Van Vollenhoven niet en zou waarchijnlijk, zonder hèm, ook thans nog niet gevormd zijn. Hiertoe was alleen in staat iemand als hij, bij wien de hoogste intellectueele gaven gepaard gingen met haast onbegrensde werkkracht. Hierbij kwam, dat Van Vollenhoven zich bijzonder tot het oosten voelde aangetrokken. Zooals bekend, 
begon hij zijne leidsche studie in twee gansch verschillende richtingen, en deed hij tegelijkertijd zijn candidaats in de semietische letteren en in de rechten. En hoewel hij zich daarna meer bepaaldelijk tot de rechtswetenschap in haren geheelen omvang voelde aangetrokken, liet het oosten - waarvan geschiedenis en letteren, evenals trouwens die van het westen, hem even gemeenzaam waren als dengenen, die daarvan hun speciaal studievak maakten - hem nimmer los. Het was niet een eenvoudig kennis nemen en zich eigen maken van hetgeen het oosten, en nu bepaaldelijk Oost-Indië, te bieden had, maar een intens meeleven met den oosterling door zich geheel te verplaatsen in zijn denk- en gevoelswereld. Dit maakte het hem mogelijk, om de maatschappelijke verhoudingen der Indonesiërs, nauw samenhangend met hun magisch-religieus geestesleven, volkomen te begrijpen, om hunne rechtsinstellingen, hunne normen van moraal, van zeden en gewoonten, te zien met het oog van den oosterling en zich geheel daar in te leven.

Maar dit alles maakte het ook vanzelfsprekend - want kòn het anders bij den ,mensch" Van Vollenhoven? -, dat de Indonesiër een ruime plaats in zijn warm hart is gaan innemen, dat deze steeds op hem kon rekenen, hem telkens op de bres vond staan, zoo vaak het ging om zijn goed recht, zoo vaak dit gevaar liep miskend, misvormd, mishandeld te worden. Treffend van eenvoud en waarheid was, wat - volgens mededeeling van een mijner indische vrienden de voorzitter van het Koninklijk Bataviaasch Genootschap, prof. mr. $\mathrm{J}$. van Kan, in zijne herdenkingsrede op de directievergadering, welke toevallig voor den avond na het bekend worden te Batavia van Van Vollenhoven's heengaan uitgeschreven was, o.m. zeide: „het hart, dat warmst voor Indië heeft geklopt, was het hart van Van Vollenhoven". Wij behoeven, indien dit noodig ware, zijne vele geschriften slechts even door te zien, om hiervan ten volle overtuigd te zijn: de vier in 1909 in de bestuursacademie gehouden voordrachten, verzameld onder den titel „Miskenningen van het adatrecht”; „De Indonesiër en zijn grond" (1919), een warm, stevig gedocumenteerd, wetenschappelijk betoog ter keering hoofdzakelijk van het gevaar, waarmede het indonesisch grondenrecht zich bedreigd zag door het ontwerp-1918 tot wijziging van art. 62 van het regeeringsreglement; tal van stukken uit zijn hoofdwerk „Het adatrecht van NederlandschIndië"; en verder heel de lange reeks van grootere en kleinere „opstellen over adatrecht", door zijne leerlingen verzameld en uitgegeven als IIIe deel van zijn "Adatrecht”; ongerekend de reeks 
leerzame opstellen over staats- en administratief recht overzee, verschenen in de jaargangen 1928-1930 van het Koloniaal Tijdschrift, en talrijke, dáár en elders verschenen opstellen en artikelen van koloniaal-politieken aard, welke hunne bekroning vonden in zijn laatste geschrift „Old glory” in de jongste Mei-aflevering van het Koloniaal Tijdschrift en, naar verluidt, alle eerlang in eene uitgave zijner „Verspreide geschriften” herdrukt zullen worden.

De voorarbeid, welke noodig was alvorens de systematische samenvatting van het indonesisch adatrecht kon worden ter hand genomen, is ontzaglijk geweest. Het was een, lang niet altijd opwekkende, arbeid van moeizaam, tijdroovend zamelen en uiterst critisch schiften en schikken van overal verspreid materiaal, het in zich opnemen en als één geheel van indonesich recht overzien van deze weerbarstige en grillig geschakeerde massa ruwe stof, het zich inleven daarin en doorgronden daarvan, waarvoor een eerste vereischte was, zich volkomen vrij te maken van westersche inzichten en zich te verplaatsen in het denken en voelen, leven en streven van den oosterling; het was een arbeid van intensief, volhardend vorschen. Niet velen zouden zulk een arbeid tot een gelukkig eind hebben gebracht, een arbeid, waarbij het menigmaal noodzakelijk bleek om tegen koppig onverstand of zelfzuchtige eigenbaat ten strijde te trekken. Doch allerminst heeft Van Vollenhoven zich laten neerslaan door de - gelukkig naast óók veel hooge waardeering - hem in ruime mate ten deel gevallen miskenning; onwankelbaar bleef zijn vertrouwen in ,het onbaatzuchtige in het recht”, steeds wist hij te vinden ,de poezie in het recht". Onverdroten, kalm en rustig zette hij zijn zwaren arbeid voort, de ongeduldigen erop indachtig makend dat to climb steep hills requires slow pace at first (Henry the Eighth) ${ }^{1}$ ), onverpoosd en onverstoord, totdat ten slotte als schitterend resultaat de twee statige deelen van zijn ,Adatrecht van Nederlandsch-Indië" gereed waren.

Hiermede was de strijd om het adatrecht voor het grootste gedeelte ten einde gebracht, de ontkenning van het bestaan van een mooi en rijk indonesisch adatrecht voor altijd onmogelijk gemaakt; hiermede tevens heeft Van Vollenhoven voor dit door hem tot wetenschap gevormd recht, èn onbedoeld ook voor zich zelven, een grootsch en stevig monument op hechte fundamenten opgericht, waarop ,de tand des tijds" zal blijken nimmer vat te kunnen krijgen.

1) Op den omslag van aflevering 3 van Adatrecht I. 
Wil men de groote beteekenis van Van Vollenhoven's arbeid op adatrechtelijk gebied ten volle beseffen, zoo moet men nagaan, wat vóór hem, vóór den aanvang van onze eeuw, en ook nog daarna, door anderen op dit gebied is gedaan. Hijzelf heeft hiervan een volledig overzicht gegeven in zijn in 1928 verschenen boekje „De ontdekking van het adatrecht”, waarin de naam van den éénigen ,ontdekker" slechts op het titelblad te vinden is, terwijl van diens talrijke geschriften niet één erin genoemd wordt. Toch kon in dat overzicht zijn baanbrekende arbeid moeilijk geheel verzwegen worden; maar daarvan wordt slechts gewag gemaakt in een allersobersten, volstrekt-onpersoonlijken vorm, achter welken hij zich zorgvuldig verborgen hield. Men vindt dien arbeid in hoofdzaak vermeld op blz. 129-130, verscholen in hoogsteenvoudige mededeelingen, waarachter iemand, die Van Vollenhoven's haast onbegrensde werkzaamheid in alle richtingen van adatrechtelijk vorschen niet eenigszins van nabij kent, het grootste deel van zijn machtig levenswerk nauwelijks zou hebben gezocht. Deze passage luidt als volgt:

„Van den inwendigen arbeid der universiteit te dezen blijkt niet veel anders dan wat het hooger-onderwijs-verslag der regeering jaarlijks vermeldt, tot 1925 uitsluitend onder Leiden, sinds dat jaar ook onder Utrecht. Het eerste proefschrift der nieuwe eeuw over adatrecht verscheen in 1907, en is door verscheidene andere, waaronder rijke en degelijke, gevolgd; zij schrijven niet langer om het adatrecht heen ...., maar over het adatrecht zelf. Sinds 1914 publiceert het Koloniaal Instituut een reeks „Pandecten van het adatrecht”, waarin systematisch gerangschikte citaten over adatrecht worden afgedrukt, ,bewerkt door studeerenden te Leiden” gelijk het voorbericht van deel I opmerkt.... Door de academie aangestichte overzichten van jurisprudentie nopens indonesisch adatrecht kwamen uit in 1912 (Enthoven; herdrukt 1927), 1916 (Jongeneel, in Adatrechtbundel 12) en 1924 (Van der Meulen; waarin Jongeneel is opgenomen). In engen samenhang met academische behoeften staan wijders een Literatuurlijst voor het adatrecht van Indonesië (1920; herdrukt 1927) en een uitgave Verordeningen inlandsch privaatrecht (1914; herdrukt 1926). In engen samenhang met den arbeid der universiteit zelf stond almede de instelling van een commissie voor het adatrecht te 's-Gravenhage $(1909 \ldots .$.$) , de oprichting van een$ Adatrechtstichting te Leiden (1917), en de lange reeks der adatrechtbundels, regelmatig verschijnend sinds 1910. In een dier bundels gaf Snouck Hurgronje een, bij den geest dezer periode voegende, aan- 
teekening over inlandsche adadtsystematiek.... Blijkbaar paste de hoogeschool bij dit alles veeleer het stelsel toe van de telkens op bepaalde rechtskringen geconcentreerde aandacht (de methode van Liefrinck en van Snouck Hurgronje) dan dat van universeele aandacht (de methode van Wilken), al wordt natuurlijk uit voorafgaande kennis van het bijzondere de kennis van het algemeene te gemakkelijker opgebouwd en saamgevat".

Hierin ligt, behalve wat hijzelf in woord en schrift heeft medegedeeld, in het kort ook het meeste - maar lang niet alles — besloten, wat op zijn initiatief is tot stand gebracht, en wat op zijne aanwijzing en met zijne medewerking, onder zijn toezicht en voortdurende leiding, ook door anderen werd verricht. En als tegen het eind van het werkje een ,terugblik" wordt geworpen op de geschiedenis van adatrechtbeoefening, dan lezen wij (blz. 163): „De ontdekking van het indonesisch adatrecht, voor zoover door westerlingen verricht, is te laat begonnen, is te ongestadig geweest, te grillig, vaak te dilettantisch. Nochtans schijnt het werk, binnen anderhalve eeuw, in goede baan geraakt.... De ontdekking van het adatrecht is in die anderhalve eeuw spasmodisch toegegaan, met krampen, met oogenblikken van crisis. Op het tijdvak 1783-1820 volgt windstilte; op de jaren 1865-1870 volgt windstilte; op den hoofdarbeid van Wilken-Liefrinck-Snouck Hurgronje, 1883-1894, volgt aanstonds die van Nederburgh en Alting, doch op 1904-1906 volgt wederom windstilte. De twee eerste windstilten echter beduidden teruggang, de laatste beduidt voortzetting van het werk, zonder ophef, doch met regelmaat”. En juist in 1906 verschijnt de eerste aflevering van „Het Adatrecht"! Zoo groote bescheidenheid, gepaard aan hoogste intellectualiteit en genialiteit, vindt haar wedergade niet.

Het zou verkeerd wezen, uit het voorgaande op te maken, dat alles, wat vóór Van Vollenhoven op adatrechtterrein ontgonnen werd, grootendeels van minderwaardig gehalte zou zijn geweest. De lezing van zijn „Ontdekking” leert het tegendeel; daarin wordt conscientieus verslag gedaan van het vele goede, dat door anderen, ook in den vreemde, in den loop van ruim anderhalve eeuw is gedaan, waarbij het menigmaal aan hooge waardeering niet ontbreekt. Trouwens ook zonder dit werkje weet een ieder thans gelukkig wel, dat hetgeen Snouck Hurgronje heeft geschreven over atjēsch en gajōsch adatrecht onovertroffen is, dat Liefrinck's opstellen over balisch grondenrecht tot de beste adatrechtsgeschriften gerekend kunnen worden, dat Wilken's naam ook voor het indonesisch adatrecht 
europeesche vermaardheid heeft verkregen. Namen als De Rooy, Helfrich, Westenberg hebben mede een goeden klank voor het adatrecht, om niet te spreken van vele ouderen, Muntinghe, Baud, van Twist en anderen, waarop Van Vollenhoven in zijn "Ontdekking” en elders het volle licht doet schijnen.

Het waren vooral bestuursambtenaren - juristen zijn, ook later, helaas in de minderheid - , die de kennis van het adatrecht door hunne geschriften, waaronder uitnemende, reeds in belangrijke mate hadden verrijkt. Wat Van Vollenhoven echter op het werk van dezen heeft aan te merken, is, zooals wij op blz. 96 van zijn ,Ontdekking" lezen: dat men te veel westersche rechtstermen gebruikt, hetgeen tot verwarring aanleiding geeft; dat bij hen ontbreekt ,een besef van dat oostersche in denkwijze, indeeling, waardeeringen, dat verschillen mòet van het westersche in waardeeringen, indeeling en denkwijze"; verder :, hun artikelen zijn rijk aan historiophantasie, aan verhalen hoe in een onbekend verleden het thans bestaande wel móet zijn ontstaan" (verg. ook blz. 131); en ten slotte: het is alles bijna materiaal uit de buitengewesten, alsof er op Java geen adatrecht te vinden was.

Voor deze grieven bestonden maar al te goede gronden. Kan men het ten beste geven van goedkoope theoretische opmerkingen - veelal aan Wilken ontleend en niet zelden zich bepalend tot een enkele mededeeling, dat dit of dat tot matriarchaat, of patriarchaat, of leviraat, of wàt ook is terug te voeren - vrij ongevaarlijk achten (hoezeer zij soms ook iemands ergernis wekken), anders is het gesteld met de andere tekortkomingen, welke men niet hun alleen, maar nog velen anderen, die zich aan het adatrecht overigens weinig gelegen lieten liggen, verwijten kon en kàn. Want het bezigen van westersche rechtstermen en het verwaarloozen van den oosterschen kijk op de dingen, hebben, òmdat zij het gevolg zijn van gebrek aan inzicht in oostersche instellingen, heel wat misverstand doen ontstaan bij zoovelen, in wier handen Indië's belangen werden gelegd hetzij als bestuurders of rechters, hetzij als wetgevers. Terecht heeft Van Vollenhoven dan ook keer op keer met kracht op het hieruit voortspruitend gevaar voor wetgeving, bestuur en rechtspraak gewezen. Krasse staaltjes van hieruit ontstaan wanbegrip, naast absoluut gemis van de meest elementaire kennis van adatrecht, werden meermalen door hem aan de kaak gesteld. Veelal waren het - beschamend genoeg! - juist juristen, en daaronder als zoodanig niet de eersten de besten, die zóó weinig zich van de romeinsch-westersche rechts- 
systematiek en terminologie wisten vrij te maken, dat zij zich zelfs aan de onvergeeflijke fout bezondigden, om volstrekt-anderssoortige indonesische rechtsinstellingen op den klank af te identifieeren met gelijknamige westersche, al hadden zij hoegenaamd niets met elkaar gemeen. Zoo de verwarring van het burgerrechtelijk bezit met het inlandsch bezitrecht op den grond, welke aan mr. Rahusen in een kamerdebat de opmerking ontlokte, dat men, in verband met de domeinleer, den Indonesiër niet ,bezitter" van zijn eigen grond mocht noemen, omdat ,,de bezitter die weet, dat een ander eigenaar is, bezitter te kwader trouw is;" een rechtskundig landraadvoorzitter acht nog in 1918 de veelvuldig voorkomende adatrechtelijke grondverpanding onbestaanbaar, omdat alleen roerend goed voor verpanding - volgens europeesch recht — vatbaar is; men sprak van ,eigendomsrecht”, zelfs van ,,dominium eminens" van district of dorp op den grond, waarop de individuen een ,,recht van vruchtgebruik" zouden hebben (vrij algemeen, zelfs een Wilken, een Kooreman, en anderen); uit een ,eigendom van den vorst op den grond" werd de domeinverklaring eertijds algemeen gerechtvaardigd (en ook thans nog gebeurt dit wel; een jurist-controleur sprak zelfs van een ,.bezit ter bede" van den tani!), de domeinverklaring, waarover zooveel verwards en verwarrends is geschreven en gezegd, dat men in een zendelingsconferentie zelfs is gaan disputeeren over ,,den domeingrond der desa ${ }^{1}$ )".

Welk een rechtsverkrachting dergelijke miskenningen - zij het ook meestal te goeder trouw - kunnen ten gevolge hebben, toonen de gegeven voorbeelden reeds voldoende aan. Voor de rechtspraak door europeesch-geschoolde juristen werd dit sterk in de hand gewerkt door de bepaling van het oude art. 75 van het regeeringsreglement, dat op inlanders hunne, godsdienstige wetten, instellingen en gebruiken" - ook al verstaat men deze woorden als stond er ,,adatrecht" zonder meer - niet mogen worden toegepast, indien zij ,in strijd zijn met algemeen erkende beginselen van billijkheid en regtvaardigheid", in welke gevallen dan steeds zoogenaamd ,,de algemeene beginselen" van het europeesch burgerlijk recht ,tot rigtsnoer” werden genomen (in de praktijk bijna steeds aldus verstaan, dat wetboekartikelen eenvoudig werden toegepast), zooals in datzelfde artikel uitdrukkelijk was voorgeschreven bij ontbreken van adatrechtelijke

1) Zie „Een adatwetboekje vcor heel Indië’, blz. 1-2; „Ontdekking”, blz. 142 ; „De Indonesiër en zijn grond”, blz. 25, 52-58; de voorbeelden zouden met een bijna oneindige reeks zijn te vervolgen. 
regelen (wat in de praktijk veel voorkwam omdat men het adatrecht niet kende).

Zoo werd de toepassing van europeesch recht op inheemschen welhaast tot regel, werd de voor hen onbegrijpelijke onderscheiding tusschen persoonlijke en zakelijke rechten hun opgedrongen, werden hun onbekende verjaringstermijnen toegepast; werden procesrechtelijk angstvallig petitoire en possessoire acties onderscheiden, niet ontvankelijk-verklaringen uitgesproken en zoo meer, en dit alles terwijl de oosterling van zijn rechter niet anders verwacht, dan dat hij de hem voorgelegde zaak geheel en al ,uit” make. Eene bepaling, welke vooral de sympathie van onze rechters had en heeft, is die van art. 1066 Ind. B. W. (art. 1112 Ned. B. W.), dat niemand genoodzaakt kan worden in een onverdeelden boedel te blijven. Hoeveel onrecht hiermede al niet is gepleegd, laat zich begrijpen, indien men weet, dat het volgens inlandsche opvattingen de natuurlijkste zaak van de wereld is, dat sterfboedels in den regel gedurende langen tijd onverdeeld blijven, stééds als er nog onmondige kinderen overblijven, dat bepaalde erfporties in het adatrecht onbekend zijn, dat bepaalde goederen nimmer worden verdeeld, dat ,onverdeelde aandeelen” in familiebezit (Minangkabau, Minahasa) een even groot onding zijn als zoodanige aandeelen in bezittingen van een rechtspersoon. Toch werd herhaaldelijk krachtens dit art. 1066 de verdeeling van familiegrond in Menado bevolen op vordering van één of eenigen onder de familieleden (door het agrarisch reglement-1918 voor Menado gelukkig onmogelijk gemaakt), zooals ook elders de verdeeling van erfboedels of van zaken, waarvan volgens adatrechtelijke beginselen verdeeling uitgesloten is.

Oneindig grooter belangen stonden er op het spel, waar onkunde en wanbegrip heerschten bij hen, die voor Indonesiërs wetten en andere regelende bepalingen te maken hadden of daarin hadden mee te spreken. Haast ongelooflijk waren soms de in de kamers over het in Indië heerschend recht gemaakte opmerkingen, zooals deze in 1896 geuite, dat het op Indonesiërs toegepaste strafrecht op den koran zou berusten (,Ontdekking”, blz. 119); ontstellend de misverstanden en verwarringen, in hetzelfde werkje op blz. $75 \mathrm{vlg}$. en elders, en verder op talrijke plaatsen in Van Vollenhoven's andere geschriften gesignaleerd. Was het wonder, als zooveel wanbegrip aan allen kant tot minachting van het onbekende leidde, tot het beschouwen van het adatrecht als lastige, onbruikbare poespas, dat hoe eer hoe beter aan kant gezet diende te worden? 
Moest Van Vollenhoven menig keer op misvattingen wijzen, anderzijds toonde hij zich verheugd telken male als hij bij anderen eenig blijk van juist inzicht in, of waardeering voor adatrecht, adatstudie, of wat daarmede samenhing, aantrof, vooral indien hij dit kon constateeren bij iemand, die geen bepaalde studie van adatrecht gemaakt, of daarvoor overigens weinig belangstelling getoond, of zelfs met onverschilligheid of erger zich daartegenover gesteld had; en zelden liet hij na, hiervan uitdrukkelijk gewag te maken, al gold het slechts eene enkele, losse opnierking. Zoo b.v. de „dankbare aanteekening” (,Ontdekking”, blz. 98) van deze, Kuyper's, uitspraak in zijn „Ons program” (1879): ,dat de inlandsche bevolking in haar eigendommelijkheid behoort te worden geëerbiedigd, en dat de archipel „,metterdaad één groep van eilanden, die sâam- en bijeenhoort”, vormt, ,een volkerenéénheid”,". Of (o.1. blz. 126) dit enkele zinnetje uit eene brochure van den semarangschen advocaat $\mathrm{mr}$. C. W. baron van Heekeren : „De kennis van het Romeinsche of Nederlandsche recht... is een struikelblok voor het vatten der Inlandsche rechtsbegrippen. Het is te betreuren, dat... niet... eene ernstige studie van de zeden en gewoonten der Inlanders van de rechters wordt gevorderd". Dan wel dit woord van Rochussen (o.1. blz. 90) : "Onderzoek eerst, en als gij onderzocht hebt en weet wat het is, maak dan bepalingen, zoo noodig bij de wet, maar niet in den blinde"; eene dergelijke uitlating van mr. Van Deventer wordt ook aangehaald op blz. 70 van „Adatrecht” III. Dankbare waardeering toont hij voor Idenburg (o.a. Adatrecht III, blz. 145, 165), voor Colijn en Kuyper (o.c. III, blz. 282-286, Ontdekking, blz. 136) ; waardeerend wordt ook melding gemaakt (Adatrecht II, blz. 490) van een rapport van $\mathrm{mr}$. Der Kinderen, waarin deze blijk gaf, het lampongsch grondenrecht goed te hebben begrepen. Waar hij merkte, iemand minder juist beoordeeld te hebben, haastte hij zich dit te rectificeeren; zie b.v. Koloniaal Tijdschrift-1932, blz. 303.

Naast de dwaling, dat men het volksrecht zou kunnen leeren kennen uit verordeningen en edicten van vorsten en hoofden, moest vooral rechtgezet worden deze, vroeger algemeen heerschende: dat mohammedanen als zoodanig door de mohammedaansche wet, hindoe's door het hindoesch recht, christenen door het christelijk recht beheerscht zouden worden, met slechts weinige, als ,,afwijkingen” van die rechten zich voordoende, uitzonderingen. Volgens Raffles was de koran bron van het recht op Java, de desa hindoesch; toch wordt Raffles' ,adatrecht” in Levyssohn Norman's dissertatie ge- 
wraakt op grond dat het onvoldoende strookte met de moslismsche wet, wat Van Hoëvell doet opmerken, dat op Java veel ,instellingen en gewoonten van de Hindoe-periode" geëerbiedigd zijn (Ontdekking, blz. 28, 30). Ook volgens Rochussen is de dorpsinrichting van Java hindoesche adat, moet individueel grondbezit een oud-hindoesch beginsel zijn (o.1., blz. 76). Het waren later vooral de hoogleeraren Keyzer en Van den Berg, die zich op dit standpunt stelden en het recht der Indonesiërs doceerden als in zijn geheelen omvang gerecipieerd mohammedaansch recht met afwijkingen; de twee befaamde opstellen van laatstgenoemde in de jaargangen 1892 en 1897 van deze „Bijdragen” over de ,afwijkingen” resp. van het mohammedaansch familie- en erfrecht en van het mohammedaansch vermogensrecht hebben deze ,leer der afwijkingen” onverbrekelijk vastgekoppeld aan den naam van prof. mr. L. W. C. van den Berg. En dit alles gebeurde, niettegenstaande niemand minder dan prof. Snouck Hurgronje reeds lang tevoren had aangetoond, dat in $c l k$ mohammedaansch land, waar ter wereld ook, het grootste deel van het rechtsleven der bevolking wordt beheerscht door adatinstellingen en slechts voor een klein deel, voornamelijk het familieleven betreffend, door islāmsche; een waarheid die door vele anderen voor onderscheidene deelen van Indonesië bevestigd, en ten slotte zelfs door Van den Berg tot zekere hoogte aarzelend aanvaard werd (Adatrecht III, blz. 355-358).

Voortreffelijk is door Van Vollenhoven in het eerste deel van zijn Adatrecht, blz. 14-38 en elders, uitgewerkt in hoofdstuk III der tweede afdeeling, uiteengezet, welk een ondergeschikte plaats godsdienstige bestanddeelen, islāmsche zoowel als hindoesche en christelijke, in het adatrecht innemen. Dat de dwaalleer der ,afwijkingen” thans gelukkig als voorgoed overwonnen mag worden beschouwd, is evenwel vooral te danken aan het feit, dat hij het hem toevertrouwde vak der ,godsdienstige wetten" van den beginne af als volksrecht opgevat, als ,,adatrecht” gedoceerd heeft, al zou deze éénig juiste, door Snouck Hurgronje gevonden, term slechts langzaam-.aan zich burgerrecht verwerven, en eerst veel later in wet en academisch statuut, in de woordenboeken der nederlandsche taal en in het spraakgebruik worden opgenomen (verg. Ontdekking, blz. 130-131).

Het kan ons niet erg verbazen, dat juristen en bestuursambtenaren, opgeleid in de leer van de receptie van het mohammedaansche recht, op Java met zijn priesterraden het adatrecht-aldaar niet zoo spoedig ontdekten; zelfs een Wilken dacht zich het javaansche volksrecht 
door den islām overwegend beinvloed. Het is weer Van Vollenhoven geweest, die aantoonde - zie reeds zijn vierde voordracht in „Miskenningen”, 1909 —, welk een schat van adatrecht juist op dat eiland te vinden was, hoeveel adatrechtelijke gegevens verborgen lagen in de verschillende regeeringsrapporten - het Eindresumé van het grondenrecht-onderzoek vooraan - en in vele andere geschriften; als men ze maar wist te vinden en te vatten. En als in Januari 1916 de zesde aflevering van „Adatrecht” verschijnt, vinden wij op de laatste bladzijde daarvan het aan Middel- en Oost-Java met Madoera gewijde 18e stuk van hoofdstuk II der tweede afdeeling aldus geestig ingeleid:

„O gij die dusver in uw lichte barke, Begeerig om te luistren, zijt gestevend Achter mijn vaartuig aan, die zingende arke,

nu wordt uw geduldig omzwerven dan ook beloond met berichten over die twee eilanden, die oorden zonder adatrecht of met bedroevend weinig adatrecht heeten: over Madoera en Java". En hij vervolgt: „Zoolang men meende het adatrecht van Java uit Java zelf te moeten verklaren, bleef, door het gebrekkige van de gegevens, teleurstelling niet uit. Toen men ging meenen het adatrecht van Java, gelijk zijn taal, te kunnen leeren uit de Vorstenlanden, raakte men bovendien van de wijs, daar vorsteninzettingen en vorstendespotie hier heel wat hadden verdrongen en veranderd. Eerst wanneer men het adatrecht van Java erkent als een doodgewoon onderdeel van dat van Indonesië, met dezelfde trekken en dezelfde tekortschietingen als het adatrecht van andere kringen, eerst dan komt het op zijn rechte plaats te staan".

Inderdaad, de eindafleveringen van het eerste deel, in October 1917 en Maart 1918 verschenen, schonken ons in 250 van de kloeke bladzijden dezer uitgave de schitterende bevestiging dezer inleidende woorden. Het daarin gegeven mooie overzicht - het éérste en tot heden het éénige - van Java's en Madoera's adatrecht zou volkomen rechtvaardigen, wat hij op blz. 140 van zijn „Ontdekking” (1928) - naar aanleiding van de geschriften van P. de Roo de la Faille, R. A. Kern, mr. C. Th. van Deventer, dr. J. H. A. Logemann, mr. F. D. Holleman, mr. B. ter Haar, en van ,een reeks van zorgvuldige, bezonnen landraadsvonnissen van Java" - met blijdschap vaststelde: „Als gevolg van het vermelde” - maar dàn te lezen: „,van Van Vollenhoven's overzicht” — ,ontmoet men dan in later jaren een feit, dat nog in 1910 ongelooflijk zou hebben geleken: 
het feit, dat het beste en het diepste adatrechtmateriaal nu dikwijls van Java komt, en juist niet langer van eilanden daarbuiten".

Uit het voorgaande kan men zoowat nagaan, hoeveel verkeerds en onmethodisch' in de beschrijving van het adatrecht bestreden, hoeveel verwarrends weggeruimd moest worden. Wie oostersche of andere vreemde samenlevingen met hare verhoudingen en instellingen wil begrijpen, dient zich zooveel mogelijk los te maken van alles, wat hij van moderne westersche cultuur in zich heeft opgenomen, moet trachten, zich onbevooroordeeld te verplaatsen in het denk- en gevoelsleven dergenen, wier zeden en gewoonten, religieuze gebruiken, rechtsinstellingen men wil leeren kennen. Alleen op deze wijze heeft men kans, iets van dit alles te begrijpen, alles in zijn onderlingen samenhang te zien. „Hebt gij een practischen werkkring”, zoo maant Van Vollenhoven zijn toehoorders-bestuursambtenaren (,Miskennigen”, blz. 40), ,,bekijk dan zoo'n volksinstelling met inlandsche oogen, stroop af de europeesche dogmata".

De gave hiertoe bezat hij zelf in buitengemeene mate en dit stelde hem in staat zich onmiddellijk thuis te voelen in de oostersche wereld, waarvan niemand de rechtsverhoudingen, -instellingen, -begrippen zoo heeft begrepen en doorvoeld als hij. Niemand als hij heeft dan ook zoo treffend de fouten vermogen aan te wijzen, die zijne voorgangers, en nog velen na hen, hadden begaan. Zoo ook is hij de eerste, die de volstrekte onbruikbaarheid van de romeinsch-westersche rechtssystematiek en terminologie voor de beschrijving van adatrecht heeft ingezien. De derde voordracht in zijne „Miskenningen” en tal van plaatsen in zijn andere geschriften handelen hierover; aan de beschrijving van het adatrecht heeft hij een eenvoudig, met den aard van dat recht strookend systeem ten grondslag gelegd, daarvoor eene passende terminologie gevonden. Van Vollenhoven heeft onmiddellijk gezien, dat de wijze waarop de oosterling zijne onderscheidingen en groepeeringen maakt, hemelsbreed afwijkt van die waarop de westerling dit doet; de oosterling gaat hierbij naiever te werk, legt aan zijne rechtsgroepeeringen en onderscheidingen, overeenkomstig zijn denkvermogen, het zinnelijk waarneembare ten grondslag, eene groepeering naar abstracte rechtsverhoudingen ligt hem verre. Zoo is b.v. onze onderscheiding in persoonlijke en zakelijke rechten hem onbegrijpelijk, daarentegen lijkt eene indeeling van rechtshandelingen ten opzichte van grond en water eenerzijds, ten opzichte van alle andere goederen anderzijds, hem zeer natuurlijk, zoodat b.v. zoowel pand als pacht van grond adatrechtelijk onder 
"grondenrecht", pand en huur en leen van roerend goed onder ,schuldenrecht" worden gebracht. Vandaar ook, dat overeenkomsten zonder meer volgens adatrecht geen verbintenissen doen ontstaan, een bindsom (pandjer) eene nog steeds meer moreele dan strengrechtelijke verbondenheid schept, maar overigens volgens oostersche begrippen elke rechtshandeling eerst met en door de overdracht of opdracht der zaak, waarop zij betrekking heeft, tot stand komt; vandaar verder, dat onze onderscheiding tusschen ,eigendom” en „bezit” buiten zijn begripsvermogen ligt.

Van Vollenhoven's geniale blik heeft dit alles reeds spoedig doorschouwd, en de juistheid van zijn inzicht vond volkomen bevestiging iil de resultaten van Holleman's adatrecht-onderzoekingen, neergelegd in zijn mooi geschrift „Het adatrecht van de afdeeling Toeloengagoeng" (1927), waaraan ik een enkel sprekend voorbeeld ontleen. Evenals zoowat overal elders namelijk, treft men in het Toeloengagoengsche rechtshandelingen aan, op grond betrekking hebbende, welke wij als verkoop, verpanding, verhuur zouden kwalificeeren, met dien verstande dat zoodanige ,,contracten” uitsluitend door en met de overdracht of opdracht van den grond tot stand komen - de ,verhuur" b.v. door afstand van den grond voor één of meer jaren of oogsten tegen zekere geldsom, ,ngedol taoenan" - ; maar daarnaast komt het bij eenvoudige geldleening zonder meer ook vaak voor, dat, wanneer de schuldenaar na herhaalde uitstelverleening nog niet in staat is het geleende bedrag terug te betalen, hij een voorwerp van waarde, een kris, een stuk vee, of ook een stuk grond aanwijst om, indien een laatstverleend uitstel zonder terugbetaling verloopt, dit als het ware tot zekerheid aangewezen, maar steeds onder den schuldenaar gebleven, stuk goed dan maar in betaling te nemen (,,djonggolan”). En nu lezen wij bij Holleman (blz. 32) : „Een even aardig als teekenend voorbeeld dat de Inlander dergelijke categorieën aanvoelt, ontleen ik aan een gesprek met den kamitoea van de desa Gamping (district Karangan, Trenggalek). Over grondenrecht sprekend, vroeg ik naar verschillende grondcontracten en werd daaromtrent vrij volledig ingelicht. Het benieuwde mij echter, of in de desa Gamping ook de zekerheidstelling (,djonggolan”) van grond bekend was, naast de verpanding (gadèkaké) die mij al genoemd was. Door geen zijdelingsche vragen slaagde ik er in den kamitoea op het onderwerp te brengen, tot ik den term ,djonggolan” zelf gebruikte. Verlucht en in een toon die zooveel beduidde als: „O! had dat dan dadelijk gezegd” antwoordde hij : ,menikå perkawis samboetan, sanès 
perkawis siti" (dat is een kwestie van schuld en niet van grond)". Van Vollenhoven waarschuwt ons meermalen voor de verwachting, als zou het adatrecht ons een compleet stel rechtsregels kunnen aanbieden in een mooi afgerond systeem, zóó, dat elk concreet geval daarin zijn oplossing zou kunnen vinden, zooals men zich dit - zij het ten onrechte - van ons gecodificeerd recht veelal pleegt te denken. Hiervan is, merkt hij op, geen sprake, reeds om deze ééne maar afdoende reden: „omdat het adatrecht voor het overgroote deel gewoonterecht is, en omdat regels van gewoonterecht onmogelijk kunnen opgroeien dan waar frequentie van gevallen en van rechterlijke beslissing is” (,Miskenningen”, blz. 43).

Hierbij moet men zich de functie van den adatrechter geheel anders denken dan die van den onze, en dit alweer, omdat het standpunt, waarop de oosterling zich plaatst tegenover het recht en het daarover gerezen geschil, zoo hemelsbreed verschillend is van het onze. Zijn recht, niet scherp af te scheiden van moraal, zeden en gewoonten, staat mèt dit alles in nauw verband met zijne magischreligieuze voorstellingen. Vóór alles vreest de oosterling - zooals dit voor Borneo zoo mooi is aangetoond door dr. J. Mallinckrodt de verbreking van het magisch evenwicht in gezin, familie, dorp, staatje, welke, gelijk door vele andere gebeurtenissen en omstandigheden, mede door rechtsgeschillen in het leven wordt geroepen. Hieruit ontstaat een ,hitte"-toestand, die zoo spoedig mogelijk in een toestand van ,koelte" moet worden omgezet, hetgeen slechts geschieden kan door niet alleen de onmiddellijk daarbij betrokken partijen, maar ook de familie, den stam, het dorp, de geesten van voorouders, van den grond, van de geheele natuur te bevredigen. Immers mag niet uit het oog verloren worden, dat de oosterling in zijn maatschappelijke groep nimmer als enkeling optreedt, maar overwegend als onafscheidbaar deel van alles, waartusschen hij geboren en getogen is, van zijn familie, zijn voorouders, zijn grond, zijn dorp; vandaar dat uitstooting in primitieve samenlevingen wel een der zwaarste straffen, of eigenlijk beveiligingsmaatregelen, is. Delicten zijn er adatverbrekingen, waardoor een kleinere of grootere groep magisch wordt geschaad; wat wij ,boete”, „straf” noemen, draagt hierdoor een gansch ander karakter dan aan deze woorden, in westerschen zin genomen, moet worden toegekend; het zijn middelen om verbroken magisch evenwicht te herstellen, waaronder een gemeenschappelijk zoenmaal een belangrijke plaats pleegt in te nemen. Uit dit nauw verband der gemeenschapsleden met alles wat tot die 
gemeenschap behoort, met het geheele complex van verwanten, groepsgenooten, voorouders, grondgeesten en wat niet al, vloeit voort de innige samenhang van alle sociale verhoudingen in zoodanige gemeenschap.

Dit doet gemakkelijk begrijpen, van hoe ongemeen groot gewicht de positie is hunner adathoofden, de hoofden die in eenige gemeenschap door de adat als zoodanig worden aangewezen en in wie men als het ware de verpersoonlijking ziet van alles, wat de groep als sociale, magisch-religieuze eenheid bij elkaar houdt. In dit verband kan het geen verwondering wekken, dat bijvoorbeeld een huwelijk niet alleen de personen raakt, die het willen aangaan, maar ook de wederzijdsche families, zelfs het geheele dorp; dat de ,bruidschat” en de huwelijksgiften - deze termen weer niet in westerschen zin te verstaan - veelal door familieleden, dikwijls door de dorpsgenooten bijeengebracht, anderzijds ook onder hen verdeeld worden; dat in Atjèh de keutjis (dorpshoofd) een belangrijke rol bij elk huwelijk speelt, over een voorgenomen huwelijk zijn veto kan uitspreken indien het dorpsbelang dit eischt.

Zonder meer is het dus begrijpelijk, dat het de hoofden zijn, die in de allervoornaamste plaats ervoor hebben te zorgen, dat de adat in alle opzichten wordt nageleefd, en óók dat zij het zijn, die „koelte” hebben aan te brengen, dat zij de angewezen rechters zijn, wanneer door eenig adatdelict, door eenig geschil van welken aard ook maar, een ,hitte"-toestand is ontstaan. Maar tevens vloeit hieruit voort, dat men onder dit ,rechtspreken” allerminst een streng toepassen van rechtsregelen heeft te verstaan, zooals onzen rechters is opgelegd te doen; dat lijdelijkheid, gebondenheid aan wettelijk bewijs, aan bepaalde procesvormen en wat dies meer zij, daarbij onbegrijpelijke zaken zijn; maar dat de adatrechter elk vóór hem gebracht geschil zoodanig te beoordeelen en tot effenheid te brengen heeft, dat, niet alleen weer de daarbij onmiddellijk betrokken partijen, maar ook ieder ander, hoe zijdelingsch belang hij daarbij moge hebben, zooveel mogelijk bevrediging kan vinden in zijne uitspraak, waaraan in het Boentoksche (Borneo) bij voorbeeld een verzoening bij vredesmaal (ngaboean) zelden ontbreekt ${ }^{1}$ ). $\mathrm{Hij}$ zal hiertoe elk rechtsgeschil in den geheelen omvang van alle daarin betrokken belangen hebben te waardeeren, door geven en nemen partijen tot elkaar zien te brengen, andere daarbij belanghebbenden hierin moeten betrekken en alles uit

1) Zie o.m. de vonnisjes in het eerste stuk van Adatrechtbundel XXXVI. 
den weg trachten te ruimen, wat aan den gewenschten toestand van algeheele ,koelte” nog in den weg mocht staan. Men ziet, hoeveel mooier de taak van den adatrechter is dan die van den onze; van den adatrechter, voor wien het summum jus summa injuria niet bestaat.

Op de beteekenis van dit alles, op de groote beteekenis van de volkshoofden voor de handhaving en de ontwikkeling van adat en adatrecht, hun bemiddelend optreden in allerhande adatkwesties, hun functie als rechters, den bemiddelenden aard en andere karaktertrekken van adatrechtspraak en nog veel meer in dit verband, kan men in Van Vollenhoven's geschriften mooie bladzijden lezen; zoo in de derde voordracht van „Miskenningen”, in zijn op den 27 en October 1908 in het Indisch Genootschap gehouden voordracht, waaraan hij eene ,proeve eener ordonnantie op de inheemsche rechtspraak” toevoegde (Adatrecht III, blz. 121-164), in hoofdstukken II en III van de derde afdeeling van Adatrecht II, blz. 247-402. Het is dan ook met voldoening, dat hij (Adatrecht II, blz. 853) de opmerkzaamheid vermeldt, welke de inheemsche rechtspraak bij de regeering is gaan vinden blijkens hare mededeelingen daarover in Indisch Verslag en Regeeringsalmanak, het aan J. C. Vergouwen opgedragen onderzoek in Tapiannoeli (zie diens verslag daarover in Serie A no. 10 der Mededeelingen bestuurszaken buitengewesten, 1930), de indiening in 1928 van een ontwerp eener ordonnantie tot regeling dezer rechtspraak in rechtstreeks bestuurd gebied - waarover zijn oordeel overigens niet onverdeeld gunstig was (zie Adatrecht III, blz. 781) -, dat geleid heeft tot de ordonnantie van Indisch Staatsblad 1932 no. 80. Anderzijds trof het hem wel smartelijk te moeten zien, hoe niet zelden juist door indonesische voorgangers hiertegen wordt gereageerd (Adatrecht II, blz. 855; III, blz. 816).

Men ziet het reeds: in deze oostersche maatschappijen kan van scherpe scheiding tusschen publiek recht en privaat recht geen sprake zijn; hoofdenfuncties van publiekrechtelijken en van privaatrechtelijken aard vloeien er in elkaar, gelijk gemeenschapsbelangen en private belangen ineenvloeien, zooals ook tusschen recht en gewoonte, tusschen recht en moraal hier minder dan ooit een scheidingslijn getrokken kan of mag worden, omdat ,overal tusschen rechtsregel en gewoonteregel, of tusschen rechtsregel en moraalregel, tusschendingen staan, die zonder verminking niet bij een der beide kunnen worden ingedeeld" (Intree-rede-1901, Adatrecht III, blz. 3).

De methode, door Van Vollenhoven gevolgd bij de beschrijving en 
verklaring van het adatrecht, verschilt hemelsbreed van die van Wilken en zijn adepten, welke men de ethnologisch-juridische of rechtsvergelijkende zou kunnen noemen. Vooral de duitsche, maar ook de engelsche en amerikaansche vertegenwoordigers dezer richting van oudere generatie (Post, Kohler, Morgan, Lubbock en anderen) hadden deze rechtsvergelijking in discrediet gebracht. Hun grootste fout was, dat zij te hard van stapel liepen, en terecht misprijst Van Vollenhoven in hen ,de onbedwongen neiging, de vleugels veel te vroeg uit te slaan. Van waargenomen verschijnselen" - zoo zegt hij, Adatrecht I, blz. 75 - ,wil men aanstonds den oorsprong kennen en de verklaring en den samenhang geven; darwinistische leuzen moeten daarbij als looper dienen; vakken als sociologie... en vergelijkende ethnologie, of zelfs socioëthnologie, worden uit hun kinderschoenen of hun luren gehaald om het luchtkasteel in èèn dag te helpen volbouwen; van een ars nesciendi schijnt men nimmer te hebben gehoord". Deze neiging, om te veel in te korten tijd te willen bereiken, wreekte zich in verschillende feilen, welke Van Vollenhoven hun met recht verwijt (Adatrecht I, blz. 74): dat men te haastig en daardoor niet met de noodige critiek te werk ging bij het verzamelen van gegevens van overal vandaan, waarvan het noodlottig gevolg was, dat deze niet steeds betrouwbaar bleken; ,dat gegevens uit levend recht en gegevens uit schoolrecht reddeloos worden dooreengeward”; ,dat overeenkomst en evenwijdigheid worden opgemerkt waar die bij nader toekijken blijken niet of in veel minder mate te bestaan". Inderdaad bleken de meeste der te haastig opgebouwde theorieën niet lang stand te kunnen houden. Wie gelooft er nog aan een oorspronkelijken toestand van promiscuiteit; aan een evolutie van moederrecht tot vaderrecht, van vaderrecht tot ouderrecht; aan de verklaring van exogamie, schaking, bruidschat uit roofhuwelijk, en aan zoovele andere fraai lijkende theorieën van een Morgan, een Mac Lennan, enz.?

Van Vollenhoven heeft ons geleerd, dat de arbeid op geheel andere wijze moest worden aangepakt, dat het de allereerste taak der rechtswetenschap is, om de geweldige massa rechtsstof, behoorlijk critisch geschift en verzameld, te onderscheiden en te ordenen, en in grootere en kleinere groepen onder te brengen. Zijn voordracht „Taalfamilies en rechtsfamilies", den 24en April 1920 in de Koninklijke Akademie van Wetenschappen te Amsterdam gehouden, - als „Families of language and families of law" in de Illinois law review van 1921 opgenomen; zie Adatrecht III, blz. 569 en 599 -, behandelt voor het geheele gebied van het recht de wijze, waarop dit ordenen en 
groepeeren dient te geschieden naar het voorbeeld van de taalwetenschap. „Mag ik het woord „rechtsfamilie” — zoo lezen wij o.c. blz. 569 - ,bezigen als wedergade van ,taalfamilie”, dan wordt de groote rechtsfamilie (in één groot rechtsdistrict) gesplitst in rechtsstammen (elk in zijn eigen rechtsbekken), die zich op hun beurt weer laten verdeelen in kringrechten (elk in eigen rechtskring), waarbeneden men alleen nog maar gouw- of streekrechten, rechtsdialecten, aantreft. Zoo kan men zich dan een Indokeltische of Indogermaansche recthsfamilie denken, daarbinnen een Germaanschen rechtsstam, daarbinnen weer een oudvaderlandsch kringrecht; of ook een Austronesische of Madagassisch-Polynesische rechtsfamilie, een Indonesischen rechtsstam, een Balisch kringrecht". Men ziet, dat bij dit groepeeren wordt uitgegaan van de taalgroepen, ,al behoeven de taalgroep, de ethnologische groep en de rechtsgroep allerminst saam te vallen" (Adatrecht I, blz. 77). Daarbij verzuimt hij niet, op het onderscheid te wijzen van wat in de taalwetenschap en wat in de rechtswetenschap wordt beoogd, en hij waarschuwt ook hier weer (Adatrecht III, blz. 570-571): ,Voor rechtsvergelijking zijn juist weinig dingen zoo gevaarlijk als zoo'n globale verkenning [als waarmede de taalwetenschap zich tevreden mag stellen], die overal wraakrecht, erfrecht, huwelijksinzettingen terugvindt, en op zulke gelijkenissen dan een ongewenschten nadruk legt. In de rechtsverkenningen over de heele wereld omvatten de rechtskringen dan ook geenszins afgescheiden rechtsgroepen, maar op zijn hoogst vermeende stadiën van éénzelfde, nagenoeg eenvormig geacht, proces van rechtsgroei; in het ratjetoe van Kohlers bijdragen tot de serie Allgemeine Rechtsgeschichte wordt dit heele vraagstuk nog evenmin gevoeld als in de rechtsvergelijkingen van Sir William Jones uit de achttiende eeuw."

Toch is het waarlijk niet uitsluitend blaam, wat Van Vollenhoven voor de ethnologische rechtswetenschap over heeft. „Haar deugden”, zoo lezen wij in Adarecht I, blz. 73, ,springen bij eerste ontmoeting $\mathrm{al}$ in het oog. $\mathrm{Zij}$ levert, vooreerst, een doorschouwing (Durchmusterung, zeggen de astronomen) van al wat op aarde van haar gading te vinden is; acht niets onbelangrijk; draagt materiaal aan op volle armen. $\mathrm{Zij}$ brengt, verder, in dien baaierd alvast wat orde, door hetzij het recht van lagere en van hoogere soorten van rechtsgemeenschappen (bloedgemeenschappen, gebiedsgemeenschappen, vorstenrijkjes, enz.) bijeen te zetten, hetzij de stof te ordenen naar onderwerpen (erfrecht, strafrecht, enz.). Zij geeft, eindelijk, door wat zij van primitief verwantschaps- en huwelijksrecht, van de opkomst van een- 
hoofdig gezag enz. blootlegt een hoog noodige correctie van het rechtsbeeld uit de gewone bijbelsche geschiedenis, die het gezinsleven der aartsvaders, de herkomst der dertien stammen, het koningschap van Saul beschrijft als hedendaagsche zaken in een oud kleed".

En allerminst achtte ook Van Vollenhoven de taak der rechtswetenschap tot systematiek beperkt. Men behoeft alleen reeds zijn schitterende inaugureele rede „Exacte rechtswetenschap” (1901) te lezen - een intreerede welke, zooals prof. Van Eysinga het zoo treffend zegt (Nieuwe Rotterdamsche Courant van 1 Mei j.1.), met een alle registers omspannend kort akkoord een academischen werkkring inzet, die voorbeeldig mag heeten in elk opzicht —, om te weten, dat hij eerst met ,de systematische, de historische, en de vergelijkende rechtsstudie, met het naspeuren dus van gesteldheid, verloop, en regelmaat van het recht,.... het ambt der rechtswetenschap ten einde” achtte. „Het is niet drieëerlei stoffe”, voegt hij hieraan toe, ,het is een zelfde stoffe, van drieërlei zijde aangevat". Hetzelfde zegt hij in Adatrecht I, blz. 77, in verband met de bespreking der verschillende rechtsgroepen, meer gepreciseerd op deze wijze : „Ten aanzien van elk dier bekkens van recht moet men niet alleen de gesteldheid van het adatrecht, maar ook zijn historische verloop en zijn bewegingswetten pogen uit te vorschen. In elk dier rechtsbekkens (b.v. onzen archipel) zal men een aantal rechtskringen (b.v. Zuid-Sumatra, Bali en Lombok) en in de meeste dier rechtskringen weer rechtsgouwen - met haar eigen gouwrechten of rechtsdialecten - moeten onderscheiden. En nimmer zal men voorop mogen stellen dat het snit en het rechtsverloop overal eender moet zijn; in de eene rechtsgouw of rechtskring kan de rechtsstroom hebben een verloop $\mathrm{a} b \mathrm{c} \mathrm{d}$ e, in de andere een verloop a b f $\mathrm{g} \mathrm{h}$, in de eene kan de rechtsstroom in vaste bedding voortvlieten, in de andere kan de rechtsstroom bestemd zijn dood te loopen".

Zijn grootste grief tegen de ethnologisch rechtsvergelijkende methode van Kohler c.s. was, wij weten het, het critiekloos bijeengaren en samenvoegen van gegevens uit alle oorden der aarde, en het uit dit materiaal van twijfelachtige waarde opbouwen van vluchtige, fantastische theorieën.,, Het heeft ongetwijfeld zijn goede zijde gehad", zegt hij in Adatrecht I, blz. 76-77, ,dat men, na een achterstand van zoovele jaren en eeuwen, begonnen is met een oppervlakkig collectioneeren en sorteeren van al het ethnologische recht. Men zal evenzeer op den duur moeten blijven kennisnemen van elkanders werk, en de bijeenvatting zal niet mogen worden verzuimd. Doch 
men zal wijs doen - Snouck heeft hierop tegen Kohler in 1886 al gewezen (Rechtsgeleerd Magazijn $1886 \mathrm{blz} .551-553)$ - het ethnologische recht te beoefenen niet voor de heele of de halve aarde, maar met als centrum van waarneming zoodanige rechtsgroepen als men meent te kunnen overzien".

Deze beperking nu maakte, dat het overgroote deel van Wilken's werk op veel hooger peil stond dan dat zijner tijdgenooten in den vreemde, ook al omdat hij veel critischer was aangelegd dan zij. Wel was zijn methode nog die van de ethnologische rechtsvergelijking; ,,maar”- zoo leest men in „Ontdekking”, blz. 101 —, ,anders dan vele buitenlanders, concentreert hij zich van den aanvang af vrijwel op den Indischen archipel en het daarbij behoorend gebied, tot groote baat van de degelijkheid zijner uitkomsten. In 1891 roemt hij dit Indonesisch gebied als rijker aan bouwstof dan misschien eenig ander deel der wereld.... Binnen dit bijeenbehoorende gebied echter concentreert hij zich niet verder; hij neemt de vragen op naar haar onderwerp, en brengt uit alle deelen van Indonesië gegevens daarover bijeen, met verzwijging gewoonlijk van die streken welke ter zake geen gegevens leveren; met het gevolg dat men eenerzijds een uitnemend en spannend overzicht krijgt van de eenheid-in-verscheidenheid van het Indonesisch adatrecht, doch anderzijds geen afgerond beeld voor zich ziet van de onderscheiden rechtskringen. Het sterkst spreekt dit voor Java;.... de lezer der Verspreide geschriften zal uit zich zelf niet licht opmerken, hoe stiefmoederlijk bedeeld daarin de rechtskringen van Java zijn. Zijn aparte studie over huwelijks- en erfrecht van Zuid-Sumatra.... schijnt veeleer bedoeld als bewerking van stof voor één uitgelezen gebied, dan als voorloopster van concentratie op gelijksoortige, stuk voor stuk te behandelen, rechtskringen".

In laatstgeciteerde woorden nu ligt Van Vollenhoven's methode kort en bondig geformuleerd: concentratie op rechtskringen binnen het gebied van den indonesischen rechtsstam; een gebied overigens, waarvan de omvang eerbiedwaardig genoeg is, immers niet alleen den Indischen archipel omvat, maar zich uitstrekt tot Madagascar, de Philippijnen en Formosa, Malakka, Indo-China.

Dat dit uitgestrekte gebied niet een homogeen rechtsstelsel te zien zou geven, zou a priori haast wel te zeggen zijn, maar bovendien was de veelsoortigheid van het hierin te vinden recht waarlijk geen geheim. Want dat het recht der Minangkabauers geheel verschillend was van dat der Atjèhers, en beide weer heel andere instellingen 
te zien gaven dan het recht der Toradja's of dat der Baliërs, wisten de lezers van Wiken, Snouck, Kruyt en Liefrinck natuurlijk zeer goed. Geheel iets anders was het echter, om al het recht binnen het indonesisch gebied in een zeker aantal groepen te sorteeren, binnen elk waarvan het recht zich als iets specifieks vertoont tegenover dat van elk der andere groepen. Hiertoe was het noodzakelijk, de geheele rechtsstof in al haar uitgebreidheid en vertaktheid te overzien, in de gegeven rechtsverschijnselen het uiteenloopende eenerzijds, het overeenkomstige anderzijds nauwkeurig na te gaan, te schiften en saam te voegen, daarbij hoofdzaken van bijzaken te onderscheiden, om ten slotte aldus, aan de hand mede van groepeeringen welke door taalkundige en ethnologische gegevens bepaald worden - doch deze allerminst slaafs volgend - tot een afbakening van arealen te komen, waarbinnen telkens het heerschend adatrecht zich als een bijzonderlijk tot een bepaalden rechtskring behoorend geheel laat samenvatten. Tot zoodanige groepeering bleek alleen Van Vollenhoven in staat; vóór hem is zij nimmer door iemand beproefd, en hoewel hij zelf de door hem gemaakte kring-indeeling als een voorloopige beschouwde omdat ,een richtige aanwijzing van de verschillende rechtskringen eerst geschieden kan als het adatrecht overal in Indië goed doorzocht en goed getaxeerd zal zijn" - , is er na hem nog niemand geweest, die zich aan eene mogelijke emendatie heeft gewaagd.

Van Vollenhoven's indeeling in 19 rechtskringen vinden wij op blz. 135 van Adatrecht I; ze zijn: 1. Atjèh (het gewest zonder Gajōen Alaslanden) ; 2. de Gajō-, Alas- en Bataklanden ; 3. het minangkabausch gebied; 4. Zuid-Sumatra; 5 . het maleische gebied (Sumatraas Oostkust zonder haar batakstreken, benevens den Riau-Lingga-archipel, waarbij dan Malaka zou hooren als engelsche helft); 6. Bangka en Belitoeng; 7. Nederlandsch-Borneo; 8. de Minahasa; 9. het gorontaleesche gebied; 10. Zuidcelebes (en de boegineesche westkust van het eiland); 11. het Toradjagebied; 12. de Ternate-archipel; 13. Ambon met toebehooren (Ceram, Boeroe, enz.); 14. Nederlandsch-Nieuwguinea; 15 . Nederlandsch-Timor met toebehooren; 16. Bali met Lombok; 17. Middel- en Oost-Java met Madoera; 18. de Vorstenlanden; en 19. Westjava (de Pasoendan).

„Men zou echter dwalen”, merkt Van Vollenhoven verder op, ,zoo men aannam dat het rechtsverschil tusschen deze kringen zich beperkte tot verschil van specieele voorschriften, overal gevat in eenzelfde raam. Neen, het raam juist is telkens van ander fatsoen,.... en wel voor een belangrijk deel wegens de uiteenloopende gesteldheid 
der inheemsche rechtsgemeenschappen hier en ginds in Indië, een gesteldheid waarmee het verdere adatrecht in onverbrekelijk verband staat. Op dezen factor wordt meestal ... niet genoeg gelet. Wel doet de ethnologie opmerken hoe de verwantschapsordening in verschillende streken is - naar stammen (geslachten), naar families, naar gezinnen - en door welk stel regels zij beheerscht wordt - collectieve of individueele verwantschap; moederrecht, vaderrecht, ouderrecht -; doch de rechtswetenschap heeft na te gaan wat de beteekenis dier verwantschapsgroepen voor het rechtsgezag is, heeft cp te merken dat de familie in de Minahasa of in het minangkabausche gebied een gansch andere rechtswaarde heeft dan de familie op Java; dat het gezin nergens in Indië zulk een rechtsbeteekenis schijnt te bezitten; en welke territoriale rechtsgemeenschappen er thans bestaan".

Het geciteerde vormt eene toepassing op het adatrecht van hetgeen van alle recht, zonder onderscheid, geldt: ,... want wij spreken pas dan van recht" - aldus uitte hij zich in zijn intree-rede, blz. 5 ,als de opvolging van een gedragregel niet slechts door voordeel en nadeel, prijs en blaam, maar door dwang - als geleider van gebod en verbod - wordt geschoord. Waar dus een gezag ontbreekt, bereid en in staat om de nakoming van regels af te dwingen, ontbreekt recht; slaapt zulk een gezag, het recht ligt werkeloos; en gedragregels door zulk een gezag niet meer of nog niet tot recht geijkt, hebben slechts voor het recht van verleden of toekomst, niet voor dat van het heden, beteekenis. De rechtsverscheidenheid op aarde ligt dus vooreerst aan de verscheidenheid dier tallooze gemeenschappen die men, in tegenstelling tot de anarchische, rechtsgemeenschappen heet en op wier gezag het recht leunen moet; anderdeels aan den steeds woeligen overvloed van het rechtsprodukt dier alle; eindelijk aan het meer of minder van feitelijke macht waarin de gezamenlijke rechtsgemeenschappen de deelen van dat rechtsprodukt weten te handhaven".

De noodzakelijkheid om het recht in allernauwsten samenhang te beschouwen met de rechtsgemeenschappen, waarin het zich vormt, ontwikkelt en op een bepaalden tijd voordoet, doet zich wel heel duidelijk gelden bij die rechten en gemeenschappen, welke in tijd, in plaats, in ontwikkeling ver van de onze afstaan; voor het adatrecht bleek dit reeds hierboven, waar gewezen werd op den grooten invloed der adathoofden op de vorming, de handhaving, de ontwikkeling van dat recht. Van Vollenhoven heeft dan 
ook aan de indonesische rechtsgemeenschappen van alle soort, bekeken in haar onderling hierarchisch verband, steeds bijzondere aandacht gewijd, te beginnen met de eerste voordracht in „Miskenningen", uitvoerig en uitputtend in Adatrecht II, blz. 409-483, en verder, in verband met de indische bestuurshervorming, in vele nog op herdruk wachtende opstellen - - zoo in Koloniaal Tijdschrift-1929, 1)lz. 99-122, in de April-aflevering van De Gids-1930, in de Economisch-Statistische Berichten van 10 September 1930 -, alsmede in tal van stukken in de Nieuwe Rotterdamsche Courant van 1929-1932, welke onmiskenbaar zijn hand verraden. Doorloopend heeft hij het adatrecht in innigsten samenhang met de verschillende indonesische rechtsgemeenschappen bezien en beschreven, aldus het in zijne eigenaardigheden kunnen doorgronden en verklaren. Wij vinden dan ook in al zijne uiteenzettingen de rechtsgemeenschappen steeds vooropgeschoven, het gezamenlijk rechtsproduct daarachter geplaatst, daarin geschoven, daaruit verklaard. En het kan ons niet verwonderen te zien, dat hij tot het allerlaatste toe (zie zijn Old glory) met alle energie pal heeft gestaan bij elke poging, elke daad, die op knotting, verwringing, vernietiging van inheemsche rechtsgemeenschappen was gericht, steeds erop aandringend, dat zij worden hersteld in haren natuurlijken vorm, gehandhaafd in haar natuurlijk wezen, in de gelegenheid geplaatst zich vrij te ontplooien en te ontwikkelen.

Een overzicht van de hoofdvormen waarin de indoneische rechtsgemeenschappen zich voordoen, wordt in Adatrecht I, blz. 136-145 gegeven. Vooreerst de genealogische groepen, bloedgemeenschappen, gevormd en voortgezet door gemeene afstamming; nergens in indonesisch rechtsgebied zoodanig aangetroffen, dat die groep de éénige gezag- en rechthebbende is, noch zoodanig, dat, onder den stam, families doch geen individuën als rechtdragers optreden; maar wèl vindt men er streken: $a$. waar onder den stam of het geslacht de individuën als rechtsdragers voorkomen (Gajo's, Dajaks van het binnenland, Timor); of $b$. waar de stam als geheel geen rol van rechtsgemeenschap speelt, maar die rol uitsluitend toekomt aan de kleinere, bijeenwonende groepjes uit den stam, de stamgenootendorpen (het Toradja-gebied en een deel van den Ternate-archipel); $c$. waar de stam families als rechtsgemeenschappen onder zich heeft en dan individuën als rechtsdragers daaronder kent (op Boeroe en Seran, waar men boven de individuën de familie, daarboven den stam, en weer dáárboven den stammenbond aantreft, en bij de Minangkabauers en Minahassers in een vorig stadium van hun recht). 
moederrechtelijke families en geslachten, die alle zijn ondergebracht in de vier soekoe's of geslachtenunies, waarvan er twee tot vier in clke nagari vertegenwoordigd zijn en aan het hoofd waarvan de uit de mamaq's der kernfamilies aangewezen panghoeloe's staan. Niet minder meesterlijk is de beschrijving van de telkens geheel anders gevormde rechtsgemeenschappen in de Minahasa, in de Bataklanden, op Borneo of in het Toradjagebied, in de ambonsche Molukken, de Timorgroep, of in welken kring ook maar, en, in nauw verband daarmede, van bestuur en rechtspraak, van familie- en erfrecht, van grondenrecht, schuldenrecht, delictenrecht. De rijkdom aan gegevens uit de javasche rechtskringen was eene verrassing. Mooi weet hij de echt-indonesische begrippen ontrent erfrecht in Middel- en Oost-Java, overeenkomende met elders gevondene, in cnkele bladzijden te schetsen; kort en bondig te schilderen de desa in denzelfden rechtskring als haast aartsvaderlijke gemeenschap, met haar hoofd en zijn trawanten, met haar oudsten en haar kerndorpers en andere bewoners, met haar functies in allerlei richting, culmineerend in de op velerlei wijze zich uitende zorg voor de economische belangen, voor dorp en dorpelingen gelegen in den onder het dorpsbeschikkingsrecht vallenden grond. Op dit beschikkingsrecht over den grond, dat bijna overal, hier sterker, daar zwakker, in het indonesisch gebied wordt aangetroffen en slechts in enkele rechtskringen nagenoeg geheel verdwenen is, heeft Van Vollenhoven als eerste de volle aandacht doen vestigen, daarover helder licht doen schijnen. In zijn „Miskenningen” is de tweede voordracht hieraan gewijd, in zijn ,Indonesiër en zijn grond” zet hij dit recht nogmaals uiteen, in zijn Adatrecht komt het doorloopend ter sprake; het beheerscht het geheele inheemsche grondenrecht, daar alle rechten op den grond hieruit zijn voortgevloeid, hierdoor worden bepaald, hierin zijn beklemd; het doet zijn invloed gelden op zoowat alle grondtransacties van eenige beteekenis, brengt zelfs verantwoordelijkheid van de gemeenschap mee voor binnen den beschikkingskring gepleegde delicten.

Men zou tot het oneindige kunnen doorgaan met te wijzen op al het voortreffelijke in zijn Adatrecht; welk onderdeel van deze ongeëvenaarde samenvatting van indonesisch adatrecht men ook zou willen grijpen, altijd kan men daarvan verklaren dat het is: magistraal in zijne bondige, doorvoelde, rake kenschetsing. Aan dit eerste deel van dit, zijn meesterwerk is bij zijne voltooiing in 1918 dan ook terecht de zeldzame Thorbecke-prijs ten deel gevallen; voor 
Nederland en Indië is het een kostelijk geschenk, waarvan de waarde niet hoog genoeg kan worden aangeslagen.

Bij dit eerste deel sluit het tweede, waarvan de laatste aflevering in September 1931 is verschenen, zich waardig aan; hiermede was dit Nederlandsch standaardwerk geheel gereed gekomen. In dit deel wordt - met uitzondering van de eerste 230 bladzijden, die over het adatrecht der uitheemsche oosterlingen en over de godsdienstige bestanddeelen van het adatrecht handelen - het indonesisch adatrecht samenvattend uit verschillende oogpunten bekeken; achtereenvolgens worden behandeld zijne handhaving, zijne inlijsting in het rechtsgeheel van Nederlandsch Indië, zijn verleden en zijn toekomst. Van den buitengemeen rijken inhoud van dit deel is in de Februariaflevering van De Gids-1932 getracht eenig begrip te geven; om herhalingen te vermijden moge daarheen verwezen worden.

Wanneer men de groote verscheidenheid van rechtsinstellingen ziet, die niet alleen eene groepeering in negentien rechtskringen rechtvaardigt, maar vaak nog ertoe leidt om binnen den rechtskring een of meer rechtsgouwen te onderscheiden, om van vele plaatselijke verschillen niet te spreken, zoo zou men oppervlakkig tot de meening kunnen komen, dat het indonesisch adatrecht al heel weinig gemeene elementen had aan te wijzen. Niets is natuurlijk minder waar: de groote mate van plaatselijk rechtsverschil sluit allerminst rechtsverwantschap uit, zoo min als de veelheid onzer archipeltalen tot ontkenning van elke taalverwantschap zou dwingen. Toen dan ook mr. H. J. Scheuer in een opstel in Onze Eeuw-1910 de wenschelijkheid had betoogd eener samenvatting van het adat-privaatrecht over zijn geheelen omvang in grove, algemeene trekken, heeft Van Vollenhoven de mogelijkheid hiervan onmiddellijk bewezen. Na van deze hem sympathieke suggestie melding gemaakt te hebben, deelt hij in Adatrecht II, blz. 862 mede: „In 1910 werd van andere zijde eene poging gewaagd om voor het adatprivaatrecht een codificatie als door mr. Scheuer aanbevolen ... concreet te formuleeren”. Deze ,poging van andere zijde" nu was niets meer of minder dan Van Vollenhoven's meesterlijk geredigeerd „Adatwetboekje voor heel Indië”, waarin hij in 96 artikelen - de overige 15 houden wijzigings- en slotbepalingen in - , de hoofdregels heeft samengevat van hetgeen het adatprivaatrecht als over het gansche rechtsgebied geldend had aan te wijzen, met de uitdrukkelijk uitgesproken bedoeling om dit wetboekje allengs te doen aanvullen of wijzigen, naar mate de praktijk voor een of meer streken de wenschelijkheid hiervan zou hebben 
aangetoond. Aan dit adatwetboekje is van regeeringswege geen of bitter weinig aandacht geschonken, en evenmin schijnt helaas bij de rechtspraak hiervan dàt gebruik te zijn gemaakt, dat het alleszins verdiende. Het groote nut voor den gebruiker zou hierin bestaan, dat hij er in een kleine honderdtal in wetsartikelen gegoten stellingen een overzicht verkrijgt van de systematiek, waarin het adatprivaatrecht moet worden gevat, van de hierbij te bezigen terminologie, van de allervoornaamste, in hoogst eenvoudige bewoordingen neergelegde, gemeene kentrekken van dit recht.

Boven werd reeds met een enkel woord medegedeeld, dat op initiatief van een aantal zijner leerlingen zijn standaardwerk werd afgerond met een, overigens los daarvan staand, derde deel, waarin Van Vollenhoven's over adatrecht handelende verspreide geschriften opgenomen zijn, met uitzondering van de vier afzonderlijk verschenen werkjes „Miskenningen” (1909), „Adatwetboekje” (1910), „De Indonesiër en zijn grond” (1919), en „Ontdekking” (1928); inderdaad eene hoogst gelukkige gedachte. Met de in deze Augustusmaand verschenen laatste aflevering is ook dit 872 bladzijden tellend deel, den afzonderlijken titel voerend ,De opstellen over adatrecht 19011931", afgesloten; vier registers besluiten dit deel, welke niet alleen naar den inhoud hiervan verwijzen, maar ook naar dien van de vier bovengenoemde daarin niet opgenomen boekjes, t.w. een register van staats-, rijks-, en bijbladen, een van oostersche termen, een namenregister en een zakenregister.

Van Vollenhoven's geschriften verschaffen den lezer een hoog intellectueel genot niet alleen door hun inhoud, maar mede door den ongemeen pittigen, pakkenden, krachtigen stijl. Voor een beschrijving van feiten, toestanden, verhoudingen wist hij de kortste, scherpste, éénig juiste uitbeelding te vinden, voor een gedachte, een voorstelling de eenigst denkbare typeering in een enkel geestig woord. Alles wat hij het papier toevertrouwde of in voordrachten uitsprak werd, uitvoerig gedocumenteerd, met het vuur eener vaste, wèl gefundeerde overtuiging geschreven en gezegd, hierop uitgeoefende critiek veelal met een kort en afdoend wederwoord weerlegd.

Van Vollenhoven zorgde er voor, steeds met beide voeten stevig op den grond te staan. Het onafgebroken verzamelen van gegevens werd daarvoor als eerste en laatste vereischte gesteld. Het was op Van Vollenhoven's krachtig initiatief, dat het Koninklijk Instituut in Juni 1909 een commissie voor het adatrecht instelde - verstevigd door het mede op zijn initiatief in 1917 tot stand gekomen adat- 
rechtstichting te Leiden, en trouw bijgestaan door de in Batavia ingestelde commissie van bijstand, thans afdeeling-adatrecht van het Bataviaasch Genootschap —, welke zich tot doel stelt, indonesische adatrechtgegevens te verzamelen en uit te geven in Adatrechtbundels, waarvan onlangs de zes en dertigste het licht zag. Van adatrechtcommissie en adatrechtstichting was Van Vollenhoven de ziel, aan hare uitgaven heeft hij, bijgestaan door medewerkers, een groot gedeelte van zijn tijd en werkkracht gewijd. Ook in de, onder zijne leiding door zijne leerlingen samengestelde „Pandecten van het adatrecht", waarvan het laatste, tiende, deel thans in bewerking is, beoogde hij het aanwezige adatrechtmateriaal te doen verzamelen, thans door systematische rangschikking, naar onderwerp en rechtskring, van uittreksels uit hiervoor in aanmerking komende geschriften (verg. Adatrechtbundel I, blz. 1-15, XVIII, blz. 3-5; ,Ontlekking”, blz. 148-149).

Zijne bemoeiingen ter bevordering van kennis en studie van het adatrecht strekten zich ook buiten de grenzen van ons land uit. Het was op zijn initiatief dat de Koninklijke Akademie in de Union académique internationale te Parijs internationale samenwerking aan de orde stelde voor onderzoek van indonesisch adatrecht door het publiceeren van gegevens; op zijn initiatief ook, dat als gevolg hiervan o.m. besloten werd tot de uitgave in de fransche taal van een woordenboek voor het adatrecht, hetwelk zijne voltooiing nadert (Adatrechtbundel XXV, blz. 7-14; ,Ontdekking”, blz. 149). Mede op zijn instigatie werd in 1931 te Parijs een voorloopig centraal bureau voor adatrechtstudie opgericht, ten doel hebbend de adatrechtbeoefenaars van alle landen bij elkaar te brengen en adatrechtgegevens over alle deelen der aarde te verzamelen (zie het door hem met prof. R. Maunier te Parijs onderteekend communiqué in Adatrecht III, 819).

De beteekenis van Van Vollenhoven's oeuvre op adatrechtelijk gebied bepaalt zich niet tot de waarde, die het heeft voor het adatrecht om zijns zelfs wil, maar is van veel wijdere strekking, omvat het belang der rechtsstudie in het algemeen. Want wie het adatrecht der onderscheidene kringen bestudeert of zelfs maar dat van enkele der voornaamste, zal aldra gewaar worden, dat er op het mooie, wijde veld der rechtswetenschap nog heel wat méér èn heel wat interessanters te vinden is dan hetgeen bij ons en anderer wetboekenrecht te koop is, ook al is daaraan een grondige studie van oudromeinsch en oud-vaderlandsch recht ten grondslag gelegd. De studie 
van het adatrecht, thans door Van Vollenhoven overzichtelijk voor ons blootgelegd in zijne veelsoortige verschijnings- en ontwikkelingsvormen, kan den jurist het inzicht geven, dat het recht geen menschenwerk is, maar een natuurlijk product van menschelijke samenleving; al ras zal hij gewaar worden, dat zijn rechtswetenschappelijke horizont zich belangrijk erdoor verheldert en verruimt, in plaats van menschenwerk levende natuur zich voor hem openbaart. Maar verder vormt het adatrecht, bezien en belicht als door Van Vollenhoven is geschied, een waardevolle schakel in de lange keten van rechten van alle oorden en alle tijden, welke, overzien als één geheel van in groote verscheidenheid gelijksoortige verschijnselen, den rechtsbeoefenaar als van zelf voert tot eene vergelijkende rechtshistorie zooals Van Vollenhoven zich die reeds in zijne intree-rede had gedacht. „Men ziet hoe mooi de studie van het adatrecht wordt”, — zoo zegt hij in Adatrecht I, blz. 78 - ,begrepen als bijdrage tot een vergelijkende rechtsgeschiedenis der heele aarde. Men ziet hoe Nederland ook in dezen door zijn koloniaal bezit bevoorrecht is. Men ziet dus dat die studie van het adatrecht waarde heeft voor nog iets anders dan voor de praktijk van rechtspraak en bestuur in Indië”.

Toèn echter (1907) achtte hij den tijd nog niet gekomen „om een voorloopig beeld te schetsen van wat er aan recht op aarde geweest is en is; ... maar men zal toch reeds thans voor oogen moeten hebben, dat de rechtswetenschap niet de studie van dit of dat brokje van recht, maar een historisch-geographische bestudeering van alle brokken van ouder en jonger recht in hun samenhang omvat" (o.l. blz. 73). Dit einddoel achtte Van Vollenhoven aan het eind van zijn rijke leven bereikt. Want juist drie maanden vóór zijn dood, zoo deelt prof. Van Eysinga ons mede in zijn mooi, aan „Van Vollenhoven als man der wetenschap" gewijd stuk (Nieuwe Rotterdamsche Courant van 1 Mei 1933), begon hij zijne proeve eener vergelijkende rechtshistorie in den vorm van een college voor alle belangstellenden. „Wie dezen, zijn prachtigen, zwanezang” - ik kan niet nalaten deze woorden, na Colenbrander (De Gids-1933, II, blz. 261) ook hier nog eens aan te halen - ,met zijn geestig tintelende inleiding, zijn spelenderwijs voor oogen tooveren van het oude Helleensche en ander recht, zijn voortdurend werpen van het scherpste zoeklicht op wat, en waarom, elders anders was en wat hetzelfde onder anderen naam, heeft mogen hooren, moest wel onder den indruk komen van de ontzagwekkende grootte van den eenvoudigen man, die hier het hoogste, waartoe de rechtswetenschap kan geraken, aan zijn studenten 
gaf met volle handen en in kinderlijken eenvoud". Het groote werk, dat uit deze colleges had moeten komen, kan hij ons helaas niet schenken; en wie zal het bestaan, deze geweldige taak van hem over te nemen?

Van meer nabijliggend, maar onoverschatbaar belang is Van Vollenhoven's arbeid op adatrecht-terrein vooral voor Indië en voor allen, die met Indië in nauwe betrekking staan, vóór alle anderen de Indonesiërs. Dit ligt zóó voor de hand, dat deze opmerking haast banaal klinkt. En toch! dringt het overgroot gewicht van zijn geweldig werk, juist en in de allereerste plaats voor hèn, wel voldoende tot hen allen door; bevroeden zij welk een onuitsprekelijke weldaad zijn moeitevolle arbeid juist voor hèn beteekent! Van Vollenhoven zelf maakte zich hieromtrent geenerlei illusies. „Terwijl goede volkskenners uit het westen positie nemen daartegen [sc. tegen unificatiepogingen op westerschen grondslag] ..., krijgt men van Indonesische voorgangers helaas om den haverklap den indruk, dat zij niet het vraagstuk zelf zien..., maar zich vergapen aan schijn, en juist daarom eenheidsrecht begeeren, om ,den inlander" niet afgescheept te rekenen met recht, dat de Europeaan immers niet goed genoeg acht voor zich", zoo merkt hij, Adatrecht II, blz. 855, op. En, nog op het allerlaatst, in Old glory (blz. 239), ontvloeit zijn pen deze spijtige ontboezeming, die tevens een ernstige vermaning insluit: „, „Net als voor Europeanen”, ,op Europeeschen voet”, bezit voor hun [der meeste Indonesiërs] ooren tooverklank; zelfs voor die leden der bevolking, die moesten kunnen zien, dat wetboeken net als voor de Europeanen, rechtspraak net als over Europeanen, en bestuursinrichting of onderwijs net als voor Europeanen, voor het millioenental der bevolking ernstig nadeel zou beduiden.... [Er bestaat] hoop op een komende bekeering der geesten. Maar voor het oogenblik schittert het vergulde blik van ,net als de Europeanen” nog met onweerstaanbare bekoring in het inlandsche oog".

Wij gevoelen mede de gerechtvaardigde ergernis, beseffen het inteleurstellende van de gewaarwording, dat zelfs deze grootsche arbeid, goeddeels een titanenstrijd tegen onverstand en zelfzucht, deze arbeid zèlfs van een zóó in alle uitnemende opzichten zelfzame figuur als $h i j$, niet voldoende is gebleken om den Indonesiërs algemeen de hooge waarde te doen inzien van eigen recht, van recht, ,das mit uns geboren ist".

Deze teleurstelling heeft hem echter nimmer het vertrouwen in hen doen verliezen, getuige de uitspraak, welke men vindt op blz. 
167 van zijn „Ontdekking”: „Een oostersche behoeften bevredigend en tot oostersche harten sprekend adatrecht zal tegen den kortzichtigen overmoed van westersch recht alleen dan bestand zijn, indien zijn ontdekking, bijwerking, bevruchting wordt voortgezet in oosterschen geest, - en door wie beter dan door Indonesiërs?"; getuige mede de zware taak, die hij op het eind van zijn „Ontdekking” (blz. 173-175) hun op de schouders legt. En als de teekenen niet bedriegen, behoeft er niet aan te worden getwijfeld, of zij zullen toonen, zijn vertrouwen ten volle waardig te zijn. Velen toch onder hen zijn er gelukkig óók, die hem volkomen begrijpen en, diep doordrongen van de hoogheid van zijn streven, zich aangorden om naar beste kunnen in zijn geest voort te arbeiden. Ik noem hier slechts van zijne oudleerlingen een Soebroto, een Soeripto, een Koesoemah Atmadja, een Soekanto, die verdienstelijke proefschriften over adatrechtelijke onderwerpen onder zijn leiding hebben geschreven, en, laatst maar niet minst, dr. Soepomo, die, behalve met zijn proefschrift over „De reorganisatie van het agrarisch recht in Soerakarta”, zich bekendheid heeft verworven door zijn onlangs verschenen monografie van het adatrecht van West-Java, waarover en naar aanleiding waarvan prof. Ter Haar een mooi en blijgestemd artikel in de Nieuwe Rotterdamsche Courant van 11 Juni j.1. schreef onder den titel „Regeeringszorg voor inlandsch privaatrecht”. Hoeveel vreugde zou Van Vollenhoven hieraan hebben beleefd, had hij kennis kunnen nemen van deze eerste vrucht van zelfstandig adatrechtonderzoek van een zijner beste leerlingen onder de Indonesiërs (verg. Adatrecht II, blz. 869).

De breede opvatting van de levenstaak, die hij zich stelde, bracht mede, dat Van Vollenhoven zijn veelomvattende kennis niet louter der wetenschap ten goede komen deed, maar haar ook dienstbaar heeft gemaakt aan de bevordering van een eerlijke, heilbrengende staatkunde overzee; dat hij zich niet tevreden stelde met het rustig bestudeeren en beschrijven van het adatrecht, maar ook de meeste aandacht wijdde aan adatrechtpolitiek. Het was zijn verheven rechtvaardigheidszin, die hem hiertoe dreef, zijn groote liefde voor ons Indië en zijn volk, het hoog besef van Nederlands plicht tegenover zijne onderdanen overzee. Immers: „Het onderkennen van adatrecht kan ons gezag tot een zegen maken daar, waar miskennen van adatrecht zou worden tot een vloek" (Ontdekking, blz. 164); ziedaar één van die eenvoudig-ware uitspraken vol diepen zin, die in zoo 
groote menigte in zijne geschriften te vinden zijn en, saamgelezen, een keur van mooie spreuken zouden geven.

Zijn streven om, waar dit zonder bezwaar kan geschieden, den Indonesiër zijn eigen recht te doen deelachtig worden, bracht als van zelf mede het nauw verband, hetwelk hij tusschen de studie van adatrecht en van indisch staatsrecht legde; de beoefening van het een kon hij zich niet denken zonder die van het ander, en voor niets ter wereld zou hij bij zijn akademisch onderwijs de combinatie van beide leervakken hebben prijs gegeven (verg. Colenbrander in De Gids-1933, II, blz. 265). Dat Van Vollenhoven allerminst een kamergeleerde was, behoeft bij dit alles nauwelijks opgemerkt. Voortdurend hield hij voeling met zijne oudleerlingen, die in Indië een praktischen werkkring hadden, voortdurend zocht hij aanraking en samenwerking met andere mannen der praktijk; twee malen heeft hij Nederlandsch Indië zelf bezocht; van het Koninklijk Instituut en het Indisch Genootschap was hij jarenlang de voorzitter, steeds een lid, dat zich ijverigst inspande voor de bevordering van de kennis over en de belangen van Indië en zijn bevolking. En als onvermoeibaar, onbaatzuchtig strijder voor het recht vond Indië Van Vollenhoven steeds gereed om voor zijne belangen op te komen waar en wanneer dit noodig bleek. Al zijn geschriften leggen hiervan getuigenis af.

De op wetgever en regeering uitgeoefende critiek was veelal onmeedoogend, maar stééds opbouwend. Nimmer behoeft men zich af te vragen, hoe $h i j$ het dan wel zou hebben gedaan; dit werd steeds ondubbelzinnig door hem aangegeven, meermalen in den vorm van uitvoerige regelingsontwerpen, welke men slechts had over te nemen: zie zijn Adatwetboekje; zie zijne met drie anderen opgestelde „Vierentwintig ontwerpen over indisch recht” (1909), opgenomen in Adatrecht III, blz. 178-279; de met vier anderen door hem ontworpen „Proeve van een staatsregeling voor Nederlandsch Indië" (1922); het ontwerp-ordonnantie achter zijn bovengenoemde voordracht over inheemsche rechtspraak; zijn concept-artikel 122a Indische staatsregeling in Koloniaal Tijdschrift 1929, blz. 121, en zoo meer.

Mogen deze ontwerpen ook nimmer voetstoots zijn overgenomen, de invloed, dien Van Vollenhoven door zijne geschriften op wetgeving voor, en bestuur en rechtspraak in het overzeesch gebied heeft uitgeoefend, was buitengewoon; maar niet minder de energieke arbeid, die hierop was gericht. Het wegruimen van de ongelooflijke 
massa ongelooflijkste wanbegrippen en vooroordeelen doet weleens denken aan de reiniging van een Augiasstal, de taaie volharding, waarmede dergelijk wanbegrip en wanbesef àl-maar terugkeerden, dreigde deze reuzentaak meermalen tot een Sisyphus-arbeid te maken. Niettegenstaande alles bleef hij evenwel vast in zijne overtuiging, dat ten slotte de goede zaak zou triumfeeren. „Laat vrij de regeering op het Plein voortgaan het adatrecht om te roepen voor afbraak en een gebouw van juristenrecht aan te besteden waar de inlandsche bevolking immers naar hunkert, - magna est veritas, et praevalet”. Zóó beëindigt hij zijn geschrift „Geen juristenrecht voor den inlander" van 1905 (Adatrecht III, blz. 59), gericht tegen de voor de zóóveelste maal ingezette poging tot unificatie van het recht (en wel in dezen zin thans, dat het europeesch vermogensrecht voor alle bevolkingsgroepen zonder onderscheid, het europeesch familie- en erfrecht ook voor christen-inlanders en vreemde oosterlingen zou gelden). En hoewel de strijd nog. lang niet uitgestreden zou blijken, heeft de uitkomst ten slotte bewezen, dat hij goed had gezien. Want niettegenstaande, tegen alle verwachting in, gedurende de vijftien jaren daarna nog bergenhooge stapels papier met unificatie-ontwerpen zijn volgeschreven en bedrukt ach, die kostbare tijd en dat kostbare geld! - , zijn wij thans gelukkig voorgoed van deze ,nachtmerrie” bevrijd. „Van Vollenhoven had met zijn geweldige wapenen in 1905, in 1914 en in 1923 niet vergeefs op de bres gestaan" (Ter Haar in zijn bovengeciteerd artikel).

Deze jaartallen geven de hoogtepunten aan van den strijd, die van 1905 af bijna onafgebroken heeft geduurd en ten slotte tot een bevredigend eind is gevoerd; van den strijd tegen het in hare oorspronkelijke redactie zoo uiterst gevaarlijk wetsonwerp tot wijziging in hoofdzaak van artikelen 75 en 109 van het regeeringsreglement, met de daaraan gepaard gaande bedreiging van unificatie in westerschen geest van rechtspleging en privaatrecht. Deze strijd is thans op den voet te volgen in de artikelenreeks, welke van 1905 tot 1918 onder het hoofd „Inlandsch recht en inlandsche christenen” is verschenen in de Nieuwe Rotterdamsche Courant (Adatrecht III, blz. 65-117, 282, 291-314, 523, 525), en in de, mede in Adatrecht III opgenomen opstellen „Geen juristenrecht voor den Inlander” (1905), „Een antithese voor Indië” en „De September-antithese van prof. Van den Berg” (1909), „De strijd om het adatrecht” (1914), „De novelle van de artikelen 75 en 109 Indisch regeerings- 
reglement” (1915), „Nieuw Indisch recht” (1918), „Juridisch confectiewerk" (1925); ten slotte ook in bovengenoemde „Vierentwintig ontwerpen over indisch recht". Het is de machtige invloed geweest van deze geschriften, welke de in 1904 en latere jaren heerschende houding tegenover het adatrecht in zoo goed mogelijke richting heeft weten te leiden, het ontwerp-1904 ten slotte, langs het amendementVan Idsinga, de wet van 31 December 1906, de novelle van 1913, heeft doen uitloopen op de tegenwoordige artikelen 131 en 163 der Indische staatsregeling, den berg unificatie-ontwerpen van 1910 en 1920 naar den rommelzolder heeft doen verwijzen, tot heil voor Indië's inheemsche bevolking.

Van Vollenhoven had zich dezen strijd eenvoudiger gedacht, waarvoor alle reden bestond na ,den driedaagschen veldslag in de tweede kamer (10-12 October 1906)"; zie Ontdekking, blz. 134. Reeds in Adatrecht I (1907) toch meende hij, na het overzicht van de verschillende rechtsgemeenschappen (zie boven), op blz. 145-146 te mogen opmerken: „Zelfs wie geen diepere kennis van het adatrecht heeft dan in dit globale overzicht is bevat zal zich niet duidelijk kunnen maken, wáártoe geleid zou hebben het voorstel der regeering van $1904 \mathrm{om} .$. . het vermogensrecht zooveel doenlijk uniform te gaan regelen, en nog wel door oplegging van het burgerlijk wetboek, voor de inlanders uit die zoo uiteenloopende rechtsstreken.... Dat regeeringsplan intusschen is in de tweede kamer zoo degelijk gelaakt, van de groene tafel zelf en in den tekst der wet zoo beslist verloochend...., dat het beleedigend en smakeloos zou wezen te onderstellen, dat de regeering tòch nog zou willen beproeven het oorspronkelijke plan, $z$ ij het in getemperden vorm en op naam eener adviseerende commissie, in het indisch staatsblad te loodsen. Zelfs ten aanzien van de kristen-inlanders alleen is zulk een spelen met het votum der kamer van geen regeering te verwachten. Over twintig jaar zal niemand zich meer kunnen begrijpen dat het plan van 1904 ooit voorstanders heeft gehad". Hoe heel anders dit is geloopen, weten wij nu: in die twintig jaar werden wij verrast met de unificatie-ontwerpen van 1910 en 1920, en juist zoowat twintig jaren na 1907 is pas het inzicht beginnen door te breken, dat een geunificeerd recht in westerschen geest een onding heeten mag.

Onovertroffen in zijn kracht van wetenschappelijk strijder was Van: Vollenhoven vooral wanneer het gold, de rechten van den Indonesiër op zijn grond te doen erkennen, het daartegen gepleegde onrecht aan te toonen, die rechten te vrijwaren voor verdere inbreu- 
ken, ze in hun zuiverheid te doen handhaven. Wij hebben hieraan vele mooie, leerzame bladzijden te danken, niet alleen in zijn Adatrecht, vooral het tweede deel - men verzuime niet hieruit de stukken te lezen over ,domeinverklaring en staatsrecht”, ,vermogensrecht nopens onroerend goed”, ,domeinverklaring en privaatrecht” - , maar ook reeds in zijne "Miskenningen” (tweede voordracht), en dàn voornamelijk in zijn „Indonesiër en zijn grond”, met de hiermede verband houdende artikelen in Adatrecht III, blz. 522 en 551, 577, 700. Laatstgenoemd werkje had tot onmiddellijke aanleiding de bestrijding van het westontwerp-Pleyte van Mei 1918 tot wijziging van artikel 62 regeeringsreglement, beoogdende wederom na 1865 - den Indonesiër grondeigendom op europeeschen voet op te dringen. Het ontwerp kreeg een mak voorloopig verslag; , ,doch zonder dit verslag te beantwoorden, misschien in verband met buiten de kamers tot uiting gekomen verzet" - heet het leukjes (Ontdekking, blz. 137); ook anderen, als Hasselman en Vergouwen in De Gids-1920, hadden zich trouwens bij dit verzet aangesloten ,in elk geval zonder opgaaf van redenen, trok de regeering in November 1920 het ontwerp in". Hoewel de aanleiding dus reeds lang niet meer bestaat, zal dit werkje om zijne wetenschappelijke uiteenzetting van het indonesisch grondenrecht altijd zijn groote waarde blijven behouden; het is in 1925, en nogmaals in 1932 herdrukt en zal, naar te verwachten is, wel nog menigen herdruk beleven.

Nog steeds toch is de langdurige strijd om het adatgrondenrecht niet uitgevochten; Van Vollenhoven's taak is overgenomen door Logemann, Ter Haar en anderen, die met de kracht van hun gedegen wetenschap de goede zaak van het recht zullen weten te dienen; het machtig, overtuigend woord van den Meester zal daarbij echter nimmer overbodig worden. Het gaat, zooals overbekend, hierbij om de loyale erkenning van het beschikkingsrecht over den grond en om de hieruit te trekken, onontwijkbare consequenties: eerlijke, ondubbelzinnige formuleering. van dit recht in de Indische staatsregeling, en opruiming van alle hiermede strijdige regelingen, in de eerste plaats van de domeinverklaring. De hardnekkigheid van den tegenstand is voor een goed deel te vinden in de vrees, dat prijsgeving van het domeinbeginsel de europeesche landbouwindustrie vrijwel onmogelijk zou maken, dat roofbouw hoogtij zou vieren, onverantwoordelijke afstand van grond niet te keeren zou zijn, en zoo meer. Van Vollenhoven, die een open oog had ook voor de eischen der praktijk, heeft overtuigend de hersenschimmigheid van die vreezen 
aangetoond. Niet alleen toch wordt loor hem (zoo op blz. 85 en verder van „Indonesiër en zijn grond”) gewezen op het verschijnsel, dat het beschikkingsrecht de strekking vertoont om op natuurlijke wijze geleidelijk weg te slijten, dat in vele streken zelfs reeds lang de voornaamste uitingen daarvan verdwenen zijn, maar, ook afgezien hiervan, wordt met kracht van argumenten betoogd, dat voor zeggenschap over den grond de domeinleer een verouderde basis vormt en volstrekt overbodig is. „Niet als grondgerechtigde” — zoo lezen wij op blz. 101 vlg. van het werkje -, ,maar als heerscher, als wetgever, stelt een gouvernement - in Nederland zoo goed als in Indië - zijn bindende voorschriften voor land en mijnbouw. Niet de grond is voorwerp van regeling, maar wat de aan het gezag der overheid onderworpen menschen met dien grond willen doen"; en met instemming haalt hij Struycken's woorden aan: ,voor zoover de gemeenschap voor de gemeene belangen over den grond of zijne vruchten wil beschikken, maakt zij niet gebruik van een eigen subjectief recht op het grondgebied, maar doet zij de algemeene gezagsordening over de daarin begrepen personen gelden”. Reeds in ,,Miskenningen” (1909), blz. 30, uitte hij zich hieromtrent als volgt: „Ik zal op het meer dan afgezaagde onderwerp dier domeinverklaring" - helaas! men is nog àl maar bezig hierover te zàgen, nù een kwart eeuw later ! - ,ten aanzien waarvan de meeningen zoo fel tegen elkaar overstaan, niet ingaan; voor mij persoonlijk is die domeinverklaring een antipathieke wanconstructie, historisch onhoudbaar, theoretisch een bron van misvatting (ook voor den wetgever zelf) en van wanbegrip, praktisch even overbodig als gevaarlijk, en in haar gangbare interpretatie in regelrechten strijd met artikel 75 lid 3 en de bedoeling van artikel 62 lid 5 en lid 6 regeeringsreglement". Men leze de boven vermelde stukken over domeinverklaring uit Adatrecht II er maar op na, om tot de overtuiging te geraken, dat doelmatige regeling van het grondenrecht negatie van beschikkingsrecht, noch domeinverklaring van noode heeft, eerlijke regeling erkenning van het eerste, en prijsgeving van de laatste eischt.

Het is ondoenlijk om in kort bestek alle adatrecht-aangelegenheden, waarvoor.Van Vollenhoven het zwaard heeft aangegord, alle adatrecht-miskenningen, waartegen hij met kracht is ingegaan, zelfs ook maar aan te stippen. Wie zich daarvan kortst mogelijk een denkbeeld vormen wil leze dat gedeelte van Adatrecht II, waarin de inlijsting van het adatrecht in het rechtsgeheel van NederlandschIndië wordt behandeld. Verbaasd staat de lezer over de groote 
kennis, de fijngevoelde doorgronding van het wezen van de inheemsche maatschappij en haar recht. Naast zuiver wetenschappelijk vorschen wordt doorloopend getracht, waar noodig het adatrecht te voeren langs de juiste banen, te leiden in de goede richting, tot ontwikkeling te brengen langs den meest natuurlijken weg.

Want allerminst was adatrecht voor Van Vollenhoven een heilig huisje, hij allerminst een adatrecht-fanaticus. „Maar de practijk heeft ook haar eischen. Een ontzien van de rechten der bevolking ten koste van Indië's ontwikkeling en bloei zou zich aan niemand erger wreken dan aan die bevolking zelf. Het land is te goed en te veelbelovend om er een adatmuseum van te maken". Aldus leidt hij het hoofdstuk in van De Indonesiër en zijn grond, hetwelk tot titel heeft: Eischen der practijk in zake bouwvelden, en hij laakt het in de instructies voor regenten en districtshoofden op Java van 1859 en 1867, als het doel ver voorbijschietend, dat alle grond, zelfs woeste, binnen beschikkingskring der desa's er ontvatbaar wordt verklaard voor uitgifte in huur aan Europeanen. En als hij aan het eind van zijn laatste voordracht voor de bestuursacademie in 1909 zijn hoorders anspoort tot intensieve studie van de indonesische volksinstellingen, opdat Nederland in deze niet overtroefd worde ,, door den kolonialen nieuweling Duitschland", dan drukt hij hun (zie laatste bladzijde van „Miskenningen”) met aandrang op het hart: „Ons doelwit daarbij is niet de adatgeleerdheid op zich zelf, nog minder het stremmen van Indië's ontwikkeling ten gerieve van vertroetelde adatcuriosa; ons hooge doelwit is het scheppen van een niet op papier maar in waarheid goede rechtsbedeeling en goede bestuursinrichting voor onze inlanders, welke twee zonder solide kennis van volksrecht en volksopvatting niet bereikbaar zijn".

Men ziet, voor overschatting van het adatrecht behoefde men bij Van Vollenhoven waarlijk niet bang te wezen; maar wat hij eischte was, dat men Indonesiërs geen westersch recht opdringe hetwelk, door hen niet begrepen, indruischt tegen hunne rechtsopvattingen en behoeften, onderwerping waaraan hun tot een ramp zou worden; dat men geen regelingen voor Indonesiërs make zonder vooraf de volksinstellingen ernstig en grondig te hebben onderzocht, doordacht en doorvoeld; dat men bij regeling, bestuur en rechtspraak daarmede ten volle rekening houde, ze tot grondslag neme, zooveel mogelijk eerbiedige. „Ook naar mijn bescheiden meening is het noodig noch gewenscht... dat men alle volksinstellingen als onaantastbare heiligdommen eerbiedigt; ook ik voel alles voor dat ,oordeelkundig 
schiften" van wat in het adatrecht goed en niet goed is, dat nog onlangs in het Indisch Genootschap werd aanbevolen (Februari 1909 blz. $124-125)$; maar voorop ga telkens, gelijk het daar heette, ,uitgebreide en nauwgezette studie" van het bestaande, gepaard aan een overzien van elk vraagstuk, en verhoed worde een ingrijpen dat de ontwikkeling der volksinzettingen stuiten zou". Zoo sprak hij in 1909 (Miskenningen, blz. 16); hierbij kunnen wij doen aansluiten, wat hij in 1933 nog allerlaatst schreef (Old glory, blz. 239) : „Men behoeft den toegang tot het westersche allerminst te barricadeeren het tegendeel is waar -, zal westersche verbetering... hebben in te voeren, zal zelfs het oostersche waar het kan uit het westersche hebben te bevruchten. Maar door, voor ons eigen gerief, het oostersche te verwringen tot iets westersch bereidt men zich zelf teleurstelling en aan de oostersche maatschappij ontreddering".

Denzelfden geest ademen de stellingen, welke hij toevoegde aan de voordracht over La politique coloniale, in 1921 te Parijs gehouden in het Institut colonial international, waarvan de vierde aldus luidt (Adatrecht III, blz. 660): „Tant la modification de la coutume [indonésienne] que son enrichissement par des règles emprunteés au droit occidental ou cosmopolite doivent s'inspirer exclusivement des besoins, des intérêts, des conceptions et des sentiments de la société orientale des indigènes". Bij het hierop gevolgd debat zijne inzichten nogeens nader toelichtend, sprak hij o.m. deze, hem als edelen strijder voor eerlijke adatrechtpolitiek kenmerkende, woorden (o.l. blz. 664) : „Je vous prie instamment, messieurs, de vous méfier de ceux qui préconisent - comme nous l'avons entendu encore hier - qu'il est permis de déroger à la coutume, soit par amour de la production économique dont a besoin „l'humanité”, soit par amour des „principes éternels de la civilisation”, soit encore par amour du Saint-Évangile. Parmi les crimes sans nombre que nous avons commis envers nos sujets coloniaux, je n'en connais aucun qui ne se soit revêtu de ces belles devises et de ces „,vêtements de brebis.”,

Inderdaad, niets was hem, den eerlijken kampioen voor het recht, ondragelijker dan valsche leuzen, gebrek aan goede trouw en waarachtigheidszin. Verachting toont hij voor de door hem herhaaldelijk, ten slotte nog met alle energie in Old glory gewraakte neiging in de koloniale politiek om ,de werkelijkheid te vermommen achter fraaie voorhangsels en zalvende opschriften”; minachting ,,voor al die schijnhervormingen, die er op papier keurig uitzien... maar door-en-door voos blijken in het gebruik". Maar optimistisch laat 
hij op dit laatste volgen: „Er was een tijd, dat de Haagsche statengenreaal door zulk een Indischen schijn zich lieten verschalken; die tijd ligt gelukkig achter ons". En laat ons hopen: voorgoed!

Dit optimisme verliet hem zelden of nimmer, al zag hij zich meermalen daarin bedrogen, zooals in 1907 (zie boven, blz. xxxv); al ging alles niet even vlot, geen oogenblik twijfelde hij aan de gewenschte uitkomst. Deze verzekerdheid was noodig, om hem de kracht te geven en te doen behouden, tegen alle miskenning, misvatting, misverstand in, den soms hopeloos lijkenden kamp voor de goede zaak aan te binden en door te zetten. Tot het laatste toe is het vertrouwen in de toekomst hem bijgebleven. Met vreugde constateert hij in „Ontdekking” (1928), blz. 164: „, .. bemoedigend is het feit, dat, beter laat dan nooit, de regeering schijnt gewaar te worden, hoe onmisbaar ontdekking van het adatrecht moet zijn, wanneer zij, met doeltreffender organisatie van het Grootindisch rijk als oogmerk, aansluiting wenscht te zoeken bij adatgemeenschappen. inheemsche vorstendommen wenscht te ontwikkelen in oostersche lijn, dorpsrechtspraak en andere oud-inheemsche rechtspraak begeert te verstaan en te utiliseeren". En hoewel hij alle reden had zich ongerust te maken over het lot, hetwelk inheemsche rechtsgemeenschap en gemeenschapsrechtspraak bij de bestuurshervorming in de buitengewesten zoude te beurt vallen, - gegeven dat ,de bestuurshervorming sinds $1922 \ldots$ een ware kameleon-politiek geworden en gebleven" is (,Indische bestuurshervorming” in Nieuwe Rotterdamsche Courant van 20 Februari 1932, avondblad D), zonder dat scherp en duidelijk tot uiting kwam, hoe die rechtsgemeenschappen daarin aangepast zouden worden, daarentegen het door mannen der praktijk unaniem veroordeeld stelsel van het ,inlandsch districtsbestuur" daarbij stevig vastgehouden werd (zie het Gidsartikel van April 1930 en andere, hierboven blz. xxin bedoelde geschriften) - uit hij tegen het slot van zijn zwanezang Old glory (blz. 256) de hooggestemde verwachting: „Het ontzaglijk probleem, het Grootindisch rijk te organiseeren, de Indische staatsinrichting te moeten herscheppen, krijgt weer krachtige bekoring. Voor het waarachtig maken van de verknoeide inheemsche rechtspraak is alom de geest al wakker geworden, tot in Batavia toe, zelfs daar niet het laatst. De bestuursvoorziening zal in dit spoor volgen. Binnen een jaar of tien is Indië een geweldig eind op streek".

Laten ook wij deze schoone verwachting deelen en blijmoedig de toekomst tegemoet zien. Wèl is Van Vollenhoven ons ontvallen, 
zullen wij van hem geen nieuw geluid te hooren krijgen, maar zijn werk kan niemand ons ontnemen, zal blijken onvergankelijk te zijn. Want de geest, die daaruit spreekt, zal blijven waken over Indië, blijven bezielen de vele jongeren - geleerden, bestuurs- en rechterlijke ambtenaren, vele anderen - , die gereed staan zijn arbeid voort te zetten.

Den Haag, Augustus 1933. 
